\title{
The North Icelandic Jet and its relationship to the North Icelandic Irminger Current
}

\author{
by Robert S. Pickart ${ }^{1,2}$, Michael A. Spall ${ }^{1}$, Daniel J. Torres ${ }^{1}$, \\ Kjetil Våge $^{3}$, Hedinn Valdimarsson ${ }^{4}$, C. Nobre ${ }^{1}$, G. W. K. Moore ${ }^{5}$, \\ Steingrimur Jonsson ${ }^{4,6}$, and Dana Mastropole ${ }^{1}$
}

\begin{abstract}
Shipboard hydrographic and velocity sections are used to quantify aspects of the North Icelandic Jet (NIJ), which transports dense overflow water to Denmark Strait, and the North Icelandic Irminger Current (NIIC), which imports Atlantic water to the Iceland Sea. The mean transports of the two currents are comparable, in line with previous notions that there is a local overturning cell in the Iceland Sea that transforms the Atlantic water to dense overflow water. As the NIJ and NIIC flow along the north side of Iceland, they appear to share a common front when the bottom topography steers them close together, but even when they are separate there is a poleward flow inshore of the NIJ. The interannual variability in salinity of the inflowing NIIC is in phase with that of the outflowing NIJ. It is suggested, however, that the NIIC signal does not dictate that of the NIJ. Instead, the combination of liquid and solid freshwater flux from the east Greenland boundary can account for the observed net freshening of the NIIC to the NIJ for the densest half of the overturning circulation in the northwest Iceland Sea. This implies that the remaining overturning must occur in a different geographic area, consistent with earlier model results. The year-to-year variability in salinity of the NIJ can be explained by applying annual anomalies of evaporation minus precipitation over the Iceland Sea to a one-dimensional mixing model. These anomalies vary in phase with the wind stress curl over the North Atlantic subpolar gyre, which previous studies have shown drives the interannual variation in salinity of the inflowing NIIC.

Keywords: Boundary currents, overturning circulation, overflow water
\end{abstract}

\section{Introduction}

The dense overflow through Denmark Strait is the largest contributor to the lower limb of the Atlantic meridional overturning circulation (AMOC; Hansen and Østerhus 2000; Hansen

1. Woods Hole Oceanographic Institution, Woods Hole, MA.

2. Corresponding author: e-mail: rpickart@whoi.edu

3. Geophysical Institute and Bjerknes Centre for Climate Research, University of Bergen, 5007 Bergen, Norway.

4. Marine and Freshwater Institute of Reykjavík, Iceland Skúlagata 4, 101 Reykjavík, Iceland.

5. Department of Physics, University of Toronto, 27 King's College Cir., Toronto, ON M5S, Canada.

6. University of Akureyri, Nordurslod 2, 600 Akureyri, Iceland.

(C) 2017 Robert S. Pickart, Michael A. Spall, Daniel J. Torres, Kjetil Våge, Hedinn Valdimarsson, C. Nobre, G. W. K. Moore, Steingrimur Jonsson, and Dana Mastropole. 


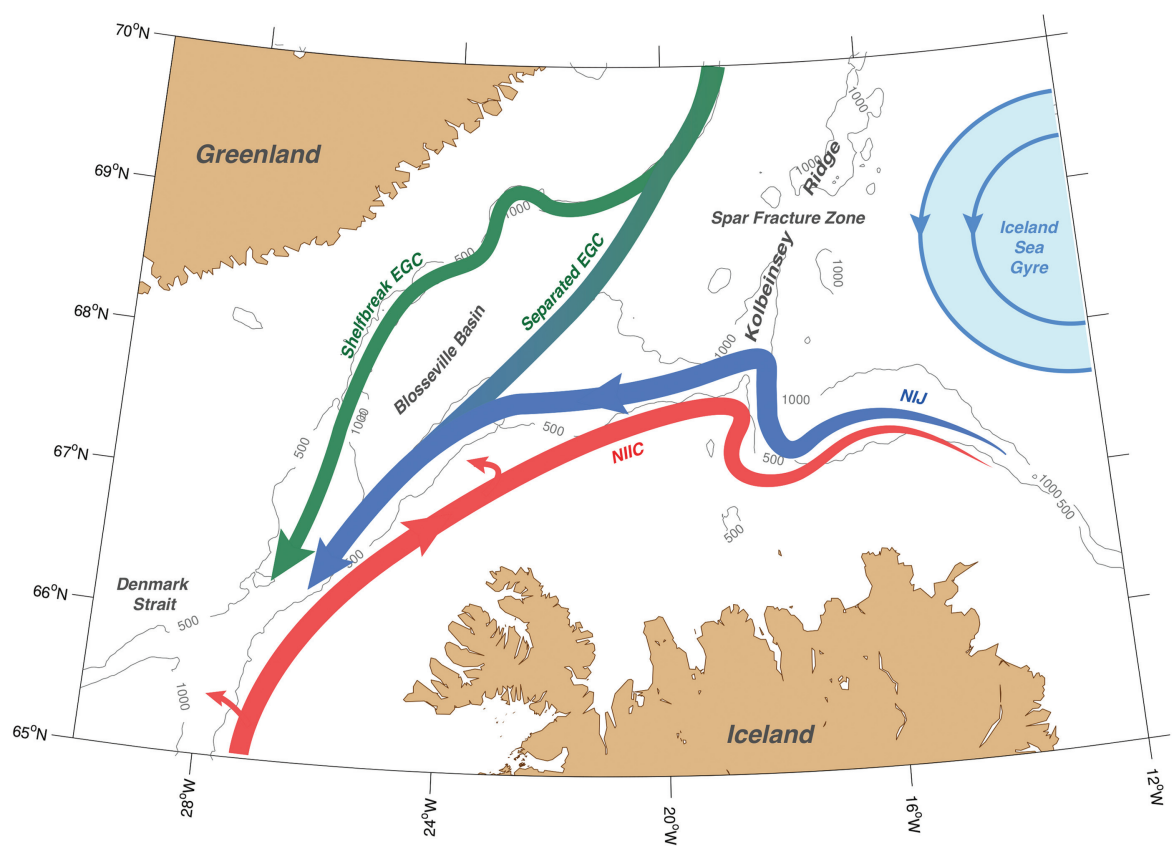

Figure 1. Schematic circulation in the region north of Denmark Strait and geographic place names, after Våge et al. (2013). The $500 \mathrm{~m}$ and 1,000 $\mathrm{m}$ isobaths are contoured in gray. EGC, East Greenland Current; NIIC, North Icelandic Irminger Current; NIJ, North Icelandic Jet.

et al. 2010). As such, it is important to understand the sources of water feeding the overflow and how the water within these pathways is made dense and delivered to the strait. Only then can we begin to determine the sensitivity of the AMOC to high-latitude climate change, including the effects of increased freshwater input to the Nordic Seas (Gierz, Lohmann, and Wei 2015; Dukhovskoy et al. 2016), changes in the air-sea heat fluxes (Moore, Renfrew, and Pickart 2012), and trends in sea-ice concentration (e.g., Moore et al. 2015). The mean transport of the overflow water exiting Denmark Strait is between 3 and 3.5 Sverdrup (Sv) (Macrander et al. 2005; Jochumsen et al. 2012, 2017; Harden et al. 2016). This represents about half of the input of dense water to the North Atlantic Deep Western Boundary Current (Dickson and Brown 1994), making Denmark Strait a critical passageway in the AMOC.

Three separate currents advect overflow water into Denmark Strait from the north: the shelf break branch of the East Greenland Current (EGC), the separated branch of the EGC, and the North Icelandic Jet (NIJ; Fig. 1). The shelf break EGC was first identified as a major source of overflow water by Mauritzen (1996). She demonstrated that the water in the Norwegian Atlantic Current was made dense by air-sea forcing as it flowed northward toward Fram Strait. Upon reaching the strait, some of the current (known at this point as the West Spitzbergen Current) recirculates to join the southward-flowing EGC (Quadfasel, 
Gascard, and Koltermann 1987; Aksenov et al. 2010; de Steur et al. 2014; Hattermann et al. 2016; Håvik et al. 2017). The resulting mixture of water masses, which includes a contribution from the Arctic Ocean (Rudels et al. 2002), ultimately flows into Denmark Strait. This warm-to-cold conversion/mixing process is known as the rim current overturning loop, and the dense water product is called Atlantic-origin water (because it has a direct pathway stemming from the Atlantic Ocean).

Recently, it has been shown that the shelf break EGC bifurcates upstream of Denmark Strait as it encounters the Blosseville Basin (Fig. 1). Using shipboard data from a number of cruises together with a numerical model, Våge et al. (2013) argued that as the shelf break EGC rounds the sharp bend in bathymetry north of the Blosseville Basin, it sheds eddies because of baroclinic instability. The eddies then migrate across the basin and rectify to form the southward-flowing separated EGC. This branch has also been identified in regional general circulation models (Köhl et al. 2007; Behrens et al. 2017). Not surprisingly, the water mass properties of the overflow water in the two EGC branches are essentially indistinguishable.

The existence of the NIJ was first reported by Jonsson and Valdimarsson (2004) using shipboard velocity data. Since then it has been observed on numerous cruises north of Iceland (Våge et al. 2011). The current is middepth intensified and is centered near the $650 \mathrm{~m}$ isobath on the Iceland slope (which happens to be the sill depth of Denmark Strait). It advects the coldest, densest component of the overflow water into the strait. Using a simplified numerical model, Våge et al. (2011) argued that the NIJ is the return branch of a local overturning loop in the Iceland Sea, which they describe as follows (Fig. 1): the North Icelandic Irminger Current (NIIC) transports Atlantic water northward into the sea; as a result of baroclinic instability, the current fluxes the water into the interior via eddies where it is densified by air-sea forcing; finally, the dense water returns to the boundary where it sinks to form the NIJ. This process has also been identified in a more realistic general circulation model (Behrens et al. 2017). The water mass product in the NIJ is referred to as Arctic-origin water because of the fact that the warm-to-cold conversion happens in the interior Nordic Seas and because there is no mean advective link from the Atlantic (in contrast to the rim current overturning loop). Jonsson and Valdimarsson (2004) argue that, as the NIJ approaches Denmark Strait, it mixes with and/or entrains ambient water from offshore of the boundary.

Using data from a yearlong mooring array deployed across the northern part of Denmark Strait, Harden et al. (2016) determined that, on average, the shelf break EGC accounts for $42 \%$ of the overflow transport $(1.50 \mathrm{~Sv})$, the separated EGC accounts for $30 \%$ (1.04 $\mathrm{Sv})$, and the NIJ accounts for $28 \%(1.00 \mathrm{~Sv})$. Notably, the degree of partitioning between these branches varies over the course of the year such that the total amount of dense water delivered to Denmark Strait remains approximately the same. Harden et al. (2016) argued that much of this partitioning is attributable to wind forcing. Using more than two decades' worth of hydrographic data from the region of the sill, Mastropole et al. (2017) revealed that the Arctic-origin overflow water from the NIJ is found in the deepest part of the strait, 
whereas the Atlantic-origin overflow water resides above this and to the west, in the vicinity of the East Greenland shelf break (the constriction of the strait forces the shelf break and separated EGC branches to move closer to each other). Downstream of Denmark Strait these overflow waters entrain ambient water from the Irminger Basin, which significantly increases the transport and modifies the hydrographic properties of the dense water plume (e.g., Dickson et al. 2008; Jochumsen et al. 2015).

Although the NIJ has now been established as a significant source of Denmark Strait overflow water (DSOW), there are a host of open questions regarding its nature, origin, and dynamics. The notion of an Iceland Sea overturning loop is still largely a hypothesis at this point. Intriguingly, the transports of both the NIJ and NIIC diminish as one progresses around the north slope of Iceland (Våge et al. 2011), such that both currents tend to "disintegrate" near the northeast corner of the island. The volume flux of each current also appears to be comparable (O(1 Sv); Jónsson and Valdimarsson 2012; Harden et al. 2016). Hence, from a mass budget perspective, the inflow of warm, light water roughly balances the outflow of cold, dense water (although this is not required for such an overturning loop). However, the relationship between the two currents needs to be explored more thoroughly. The kinematic structure and water mass signature of the NIJ also requires further investigation, including the role of mixing and entrainment in the current. Finally, quantifying the seasonal to interannual variability of the NIJ will help shed light on the timing by which the transformed water enters the current, which in turn will offer clues regarding its formation.

In this study, we use a collection of shipboard hydrographic and velocity sections occupied across the northern Iceland shelf/slope over a period of roughly a decade to better understand some of the aspects of the NIJ and its interaction with the northward-flowing NIIC. We first present the mean characteristics and seasonal variability of the two currents and then investigate their transports both in the cross-stream plane and in temperature-salinity space. This is done at a single location northwest of Iceland. Next, we consider the pathway of the NIJ as it flows toward Denmark Strait in relation to the location of the NIIC. We find that the two currents are only sometimes adjacent to each other, and we consider conditions that might influence this. Finally, we investigate the interannual variability of the overflow water in the NIJ and relate this to various driving factors, which sheds light on the link between the dense outflow through Denmark Strait and the inflowing Atlantic water.

\section{Data and methods}

\section{a. Shipboard data}

The hydrographic and velocity data used in the study come from eight shipboard surveys of the north slope of Iceland, carried out between 2004 and 2013 (Fig. 2). Five of the cruises took place in summer/fall, and the remaining three occurred in winter (Table 1). On each of the surveys, the Kögur line was occupied, which is one of the standard sections maintained by the Marine and Freshwater Research Institute of Iceland (MRI) on a regular basis. During the time period in question, eight Kögur occupations were carried out, which 


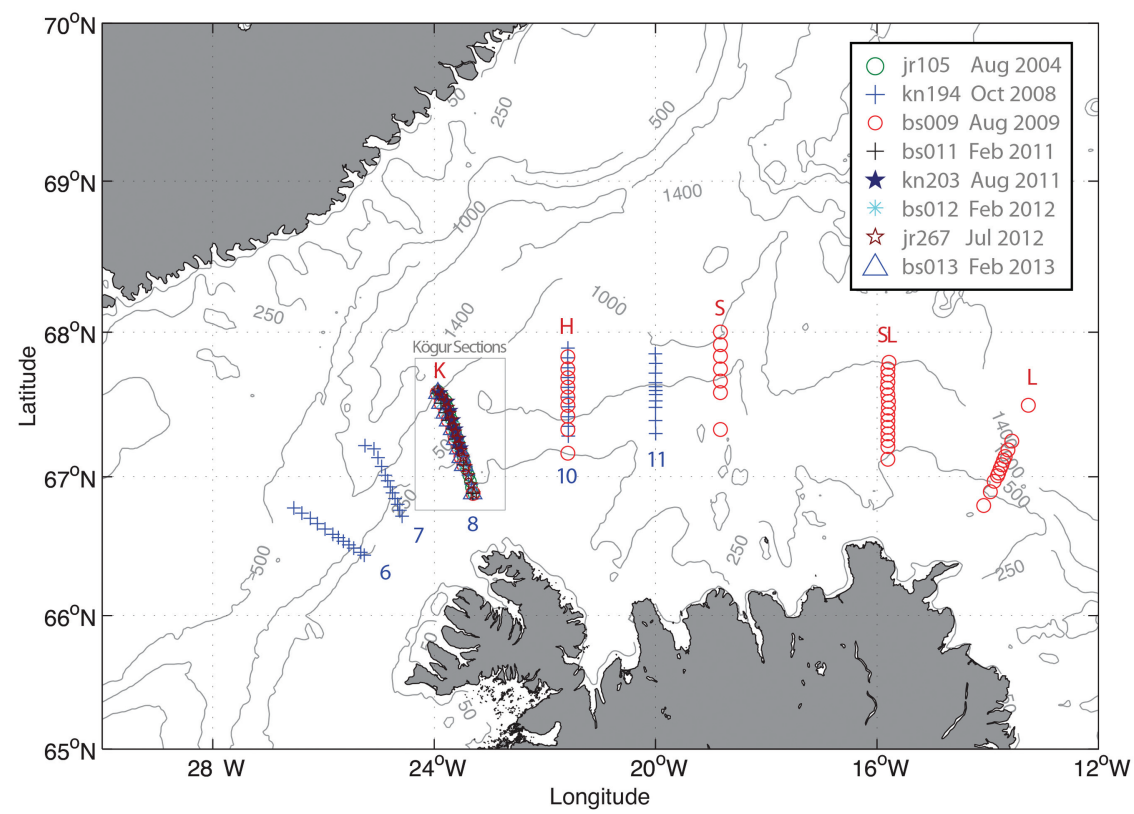

Kögur Sections
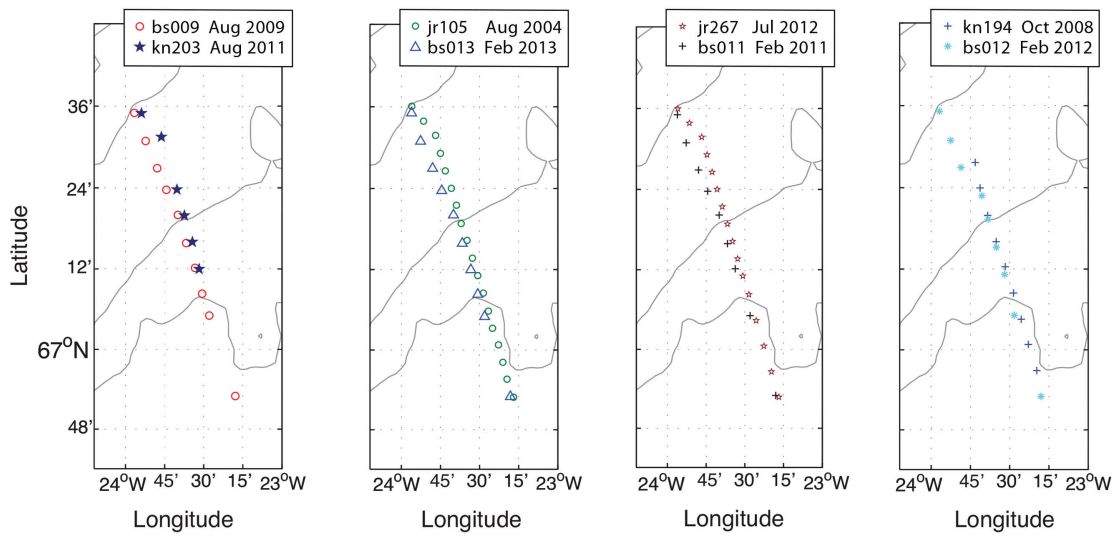

Figure 2. Top panel: Locations and labels of the shipboard sections used in the study (see the legend). Bottom row: The eight Kögur sections shown two at a time.

included shipboard measurements of hydrography and velocity (the latter is not typically measured on the MRI surveys). The remaining sections, which span from north of Denmark Strait to the northeast part of Iceland, were occupied in 2008 (the western sections) and 2009 (the eastern sections; see Fig. 2). The station spacing was typically $5 \mathrm{~km}$ or less, which is required to resolve the approximately $20 \mathrm{~km}$ wide NIJ. 
Table 1. Occupations of the Kögur transect used in the study.

\begin{tabular}{lcc}
\hline Dates of occupation of Kögur section & Elapsed time & Ship \\
\hline 08 August 2004 1511Z-09 August 2004 1345Z & $22 \mathrm{~h}, 56 \mathrm{~min}$ & RRS James Clark Ross \\
17 October 2008 0550Z-18 October 2008 1238Z & $20 \mathrm{~h}, 48 \mathrm{~min}$ & R/V Knorr \\
12 August 2009 1901Z-13 August 2009 0613Z & $11 \mathrm{~h}, 14 \mathrm{~min}$ & R/V Bjarni Saemundsson \\
11 February 2011 1836Z-12 February 2011 0532Z & $12 \mathrm{~h}, 08 \mathrm{~min}$ & R/V Bjarni Saemundsson \\
25 August 2011 2050Z-26 August 2011 2135Z & $24 \mathrm{~h}, 45 \mathrm{~min}$ & R/V Knorr \\
09 February 2012 2331Z-10 February 2012 1004Z & $10 \mathrm{~h}, 35 \mathrm{~min}$ & R/V Bjarni Saemundsson \\
30 July 2012 0543Z-31 July 2012 0611Z & $12 \mathrm{~h}, 28 \mathrm{~min}$ & RRS James Clark Ross \\
07 February 2013 2345Z-08 February 2013 1001Z & $10 \mathrm{~h}, 16 \mathrm{~min}$ & R/V Bjarni Saemundsson \\
\hline
\end{tabular}

i. Hydrography. All of the cruises used a Sea-Bird 911+ Sea-Bird Electronics, Bellevue, Washington, US. Conductivity-temperature-depth (CTD) instrument mounted on a rosette with Niskin bottles for collecting water samples. The temperature and conductivity sensors were calibrated at Sea-Bird before and after each cruise, and the conductivity values were further adjusted using the in situ salinity data. The resulting accuracies are $0.001{ }^{\circ} \mathrm{C}$ for temperature, and 0.002 for salinity. Vertical sections of potential temperature referenced to the sea surface (hereafter referred to as temperature), salinity, and potential density referenced to the sea surface (hereafter referred to as density), were constructed using Laplacian-spline interpolation. The bottom topography was obtained by the ships' echo sounder and corrected for variations in sound speed. The along-stream direction is positive toward Denmark Strait, the cross-stream direction is positive toward Iceland, and the vertical direction is positive downward. The cross-stream distance is $x$, and the depth is $z$. The $x$ origin of the Kögur line corresponds to the offshore-most station that is typically occupied by MRI.

ii. Velocity. Direct measurements of velocity in the water column were made at each station using a lowered acoustic Doppler current profiler (LADCP). This consisted of an upwardfacing and downward-facing $300 \mathrm{kHz}$ Teledyne RDI Workhorse attached to the rosette. The data were processed using the velocity inverse method from the Lamont-Doherty Earth Observatory LADCP Processing Software Package version IX.10 (Thurnherr, 2010, 2014). The methods used to develop the LADCP processing software are described by Firing and Gordon (1990), Fischer and Visbeck (1993), and Visbeck (2002). Following this, the barotropic tidal signal was removed from each profile using the $1 / 60^{\circ}$ regional tidal model of Egbert and Erofeeva (2002). The resulting uncertainty in the velocity, because of instrument error and inaccuracies in the tidal model, is $2 \mathrm{~cm} \mathrm{~s}^{-1}$ (see Våge et al. 2011). Vertical sections of absolute geostrophic velocity were created by referencing the gridded thermal wind sections with the gridded cross-track LADCP velocity sections, as was done by Våge et al. (2011). Positive velocities $(u)$ are directed toward Denmark Strait. 


\section{b. Reanalysis products}

Three different global atmospheric reanalysis products are used in the study: the National Centers for Environmental Prediction (NCEP) product, the ERA-Interim (ERAI) product from the European Center for Medium-Range Weather Forecast, and the Japanese Meteorological Agency product (JRA55). The spatial resolution of the NCEP fields is approximately $1.9^{\circ}$ for the $10 \mathrm{~m}$ winds, precipitation, and evaporation fields (Kalnay et al. 1996). The data are archived every 6 hours from 1948 onward. The ERAI data cover the period 1979 to the present (Dee et al. 2011), with an effective spatial resolution of $80 \mathrm{~km}$ and time step of 6 hours. The JRA55 is available from 1958 onward with a 6-hour time step at a spatial resolution of approximately $56 \mathrm{~km}$ (Kobayashi et al. 2015).

It should be noted that the precipitation and evaporation fields from reanalysis products are not strongly constrained by observations and are therefore influenced by the characteristics of the parameterizations used in the underlying numerical model (Kalnay et al. 1996; Renfrew et al. 2002; Dee et al. 2011). It is difficult to estimate the uncertainty in precipitation estimates from reanalyses as a result of the sparse nature of observations, especially over the high-latitude ocean (Bosilovich et al. 2008). With this caveat, it appears that the precipitation over the North Atlantic Ocean from reanalyses is biased low by up to $10 \%$ (Bosilovich et al. 2008). Based on aircraft observations from the Denmark Strait region, the uncertainty in the evaporation and the momentum flux is also on the order of $10 \%$ (Renfrew et al. 2009). Given that these air-sea flux fields are all influenced by the characteristics of the underlying models, one can assume that the errors in these fields are independent; thus using three different reanalysis products provides additional confidence in the results obtained in the study.

\section{The Kögur section: Mean, seasonality, and transports}

\section{a. Mean}

Using the eight occupations of the Kögur transect, we made mean sections of the hydrographic variables and the absolute geostrophic velocity (Fig. 3). Four of these occupations (all carried out in the summer) were used by Vage et al. (2013) in their investigation of the circulation north of Denmark Strait. Also, Harden et al. (2016) created yearlong mean vertical sections from the mooring data along the Kögur line, which are obviously more robust than those presented here. However, the spatial coverage of the moorings was not as complete as that provided by our CTD/velocity transects. In particular, the moorings had only a single CTD sensor in the top $100 \mathrm{~m}$, had coarser cross-stream resolution, and did not extend onto the Iceland shelf and hence were not able to sample the NIIC. In seven of the eight transects considered here, the stations bracketed both the NIJ and NIIC throughout the entire water column (the August 2011 occupation only sampled the offshore portion of the NIIC). As such, our data set offers a unique view of these two currents.

The mean temperature section reveals cold, dense water banked against the Iceland slope, nearly reaching the shelf break (Fig. 3a). This constitutes the densest portion of the DSOW 
(a)
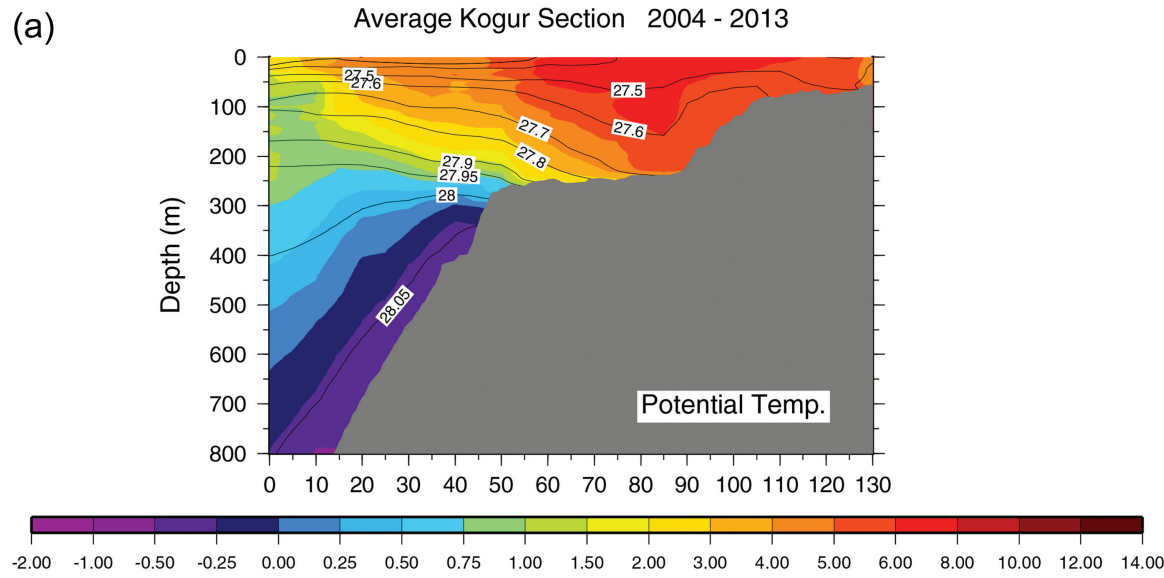

(b)

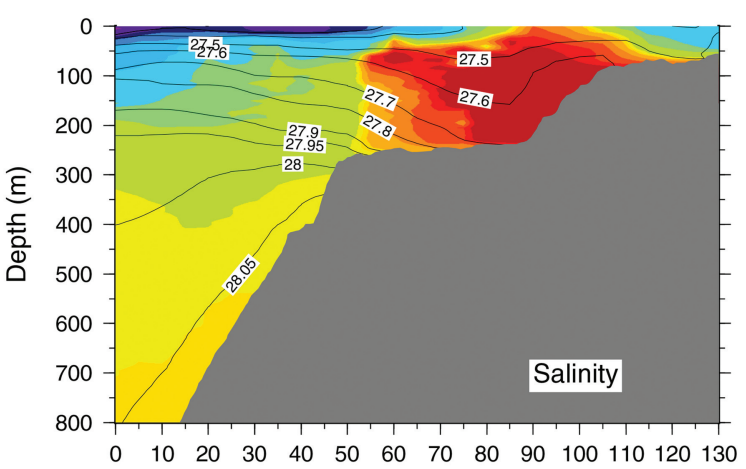

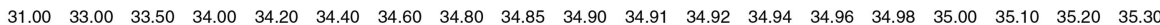
(c)
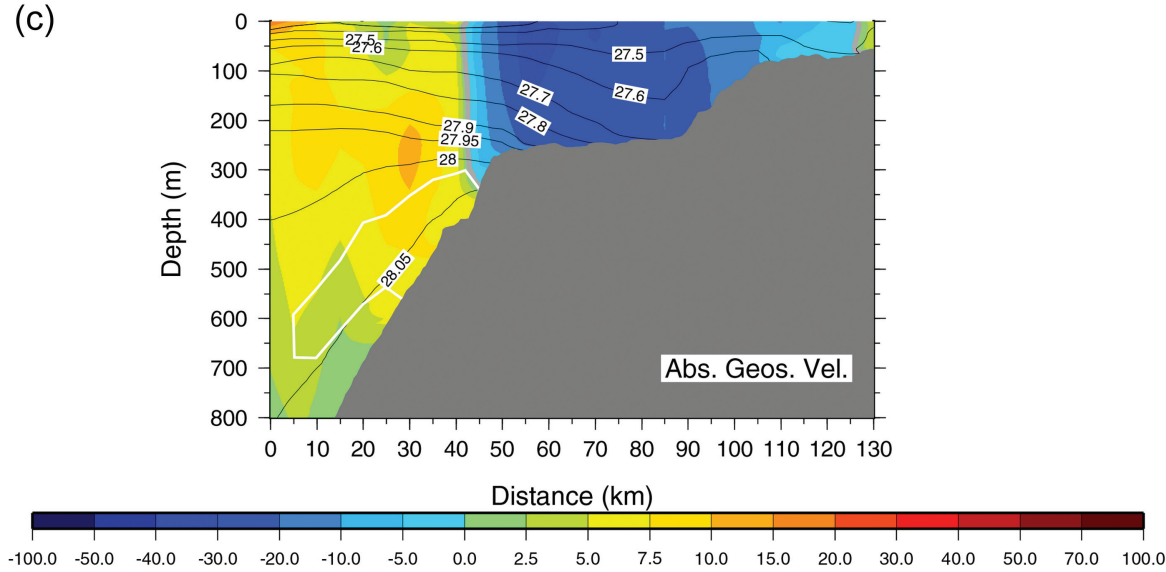

Figure 3. Mean vertical sections of the eight Kögur transects. The viewer is looking to the northeast. The contours are potential density $\left(\mathrm{kg} \mathrm{m}^{-3}\right)$. (a) Potential temperature (color, ${ }^{\circ} \mathrm{C}$ ). (b) Salinity (color). (c) Absolute geostrophic velocity (color, $\mathrm{cm} \mathrm{s}^{-1}$ ). Positive velocities are equatorward. The thick white contour in panel (c) delimits the region of the dominant temperature-salinity transport mode discussed in the text (defined by a temperature range of $-0.4^{\circ} \mathrm{C}$ to $0^{\circ} \mathrm{C}$ and salinity range of 34.90 to 34.91$)$. 
(Våge et al. 2011). It also comprises the large boluses of overflow water that are commonly observed at the sill (Mastropole et al. 2017). The Iceland shelf is mainly filled with warm and salty Atlantic water (Fig. 3a and b). The salinity section shows that this water mass is typically confined between the shelf break and the sharp change in topography near $x=105 \mathrm{~km}$ (which separates the inner and outer shelves). In addition to the pronounced hydrographic front at the shelf break, there is a second more subtle hydrographic front in the mean section near $x=10 \mathrm{~km}$ in the upper $150 \mathrm{~m}$. This also separates colder, fresher water offshore from warmer, saltier water onshore. This front is discussed in Section 4.

The mean absolute geostrophic velocity section (Fig. 3c) reveals several features. First, there is the poleward-flowing NIIC inshore of $x=40 \mathrm{~km}$. The maximum velocity of the current is near the shelf break, associated with a density front: the isopycnals slope downward going onshore, resulting in surface-intensified flow. Note, however, that the NIIC extends well onshore of this to where the bathymetry shoals again. Here the isopycnal tilt changes sign, and the flow is weakly bottom intensified. On the inner shelf, the isopycnal tilt reverses yet again. This inner front is associated with the shoreward edge of the Atlantic water where there is a transition from warm, salty water to colder and fresher water. Note that this density front is dictated by the lateral gradient in salinity, whereas the shelf break front is dictated by the lateral gradient in temperature.

The main core of the NIJ is located near $x=30 \mathrm{~km}$, corresponding to the divergence in isopycnals (which is a ubiquitous feature of the current; e.g., Våge et al. 2011): the deeper isopycnals slope downward going offshore, whereas the shallower isopycnals slope upward. As such, the current is middepth intensified with maximum flow near $300 \mathrm{~m}$. This spreading of the isopycnals is indicative of the low potential vorticity water advected in the NIJ, which supports the interpretation of a convective origin. In the upper left-hand part of the mean section there is surface-intensified flow in the top $100 \mathrm{~m}$. This is the eastern edge of the separated EGC. As demonstrated by Harden et al. (2016) using the mooring data along the Kögur line, in the yearlong mean the separated EGC and NIJ are partially merged. In Figure 3(c), deeper than $100 \mathrm{~m}$ and slightly onshore of the separated EGC, there is a second region of middepth-intensified southward flow. As shown in the next section, this signal is attributable to the fact that, at times, the NIJ has multiple cores.

\section{b. Seasonality}

To investigate seasonal differences in the water masses and currents at the Kögur line, we created mean vertical sections for the warm season (the August, July, and October occupations, five total) and the cold season (the February occupations, three total). These are shown in Figure 4, which reveals significant differences. In summer/fall, the Atlantic water on the Iceland shelf is warmer, saltier, and more strongly stratified than in winter (consistent with the results of Jónsson and Valdimarsson [2012]). There is also a nearsurface layer of freshwater extending across the shelf. In winter, the strong air-sea heat flux in the region forms a deep mixed layer that extends to within $\sim 50 \mathrm{~m}$ of the bottom. 

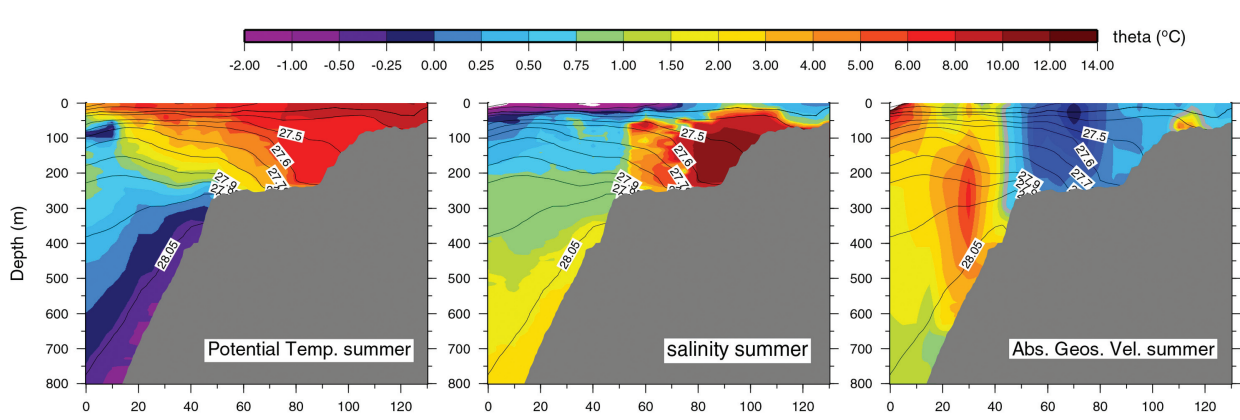

33.00033 .50034 .00034 .20034 .40034 .60034 .80034 .85034 .90034 .90534 .91034 .92034 .94034 .96034 .98035 .00035 .10035 .20035 .800
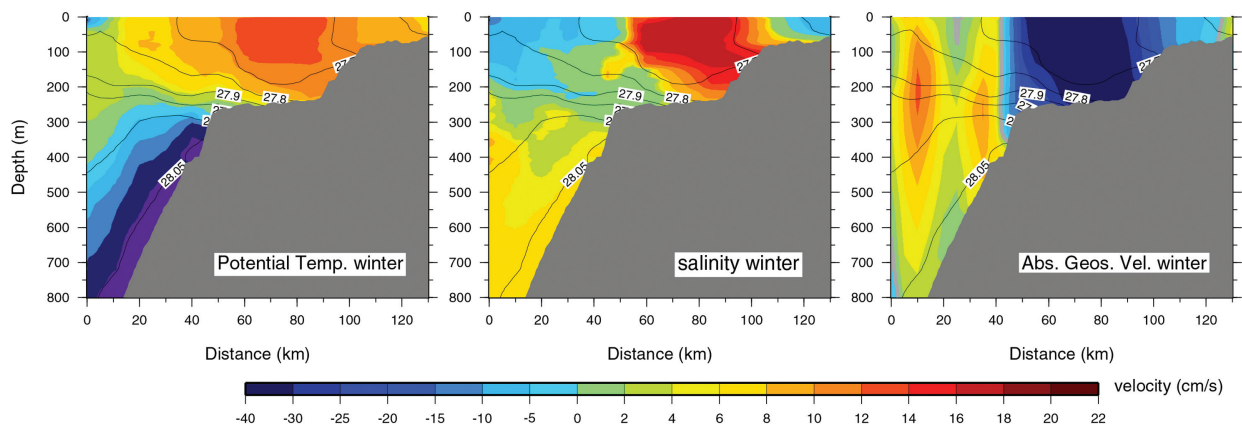

Figure 4. Top row: Mean vertical sections of the summer/fall Kögur transects (see Table 1). Bottom row: Mean vertical sections of the winter Kögur transects. The properties are the same as in Figure 3.

This convective overturning mixes the cold, fresh surface water downward, which cools and freshens the Atlantic water. Note also that in winter the NIIC is more barotropic. (It also appears to be stronger then, but this is largely because of an anomalously strong NIIC in February 2011; see Section 3c.)

The velocity seaward of the shelf break also displays seasonal differences. In summer the NIJ is well developed, centered near $x=25 \mathrm{~km}$, with a divergence of isopycnals progressing offshore (as in the overall mean section; Fig. 3). Seaward of this ( $x<12 \mathrm{~km}$ ) there is a clear signature of the separated EGC. Here the equatorward flow is surface intensified, and the isopycnals slope downward offshore throughout the water column. Note the hydrographic front associated with the separated EGC; in particular, the water in the top $200 \mathrm{~m}$ becomes colder and fresher (see also Våge et al. 2013). In winter there is no sign of the separated EGC, and now the NIJ has two separate cores (this was true in each of the three winter occupations). The inner core is located immediately offshore of the shelf break, whereas the outer core-which is stronger and extends over a greater portion of the water columnis located near the western edge of the section. Presently, it is unclear why the NIJ at times 
has multiple branches; it could conceivably be because of meandering or eddy formation. This is investigated further in Section 4.

\section{c. Volume transports in the vertical plane}

As noted previously, one of the unique aspects of our data set is that seven of the eight occupations of the Kögur section simultaneously sampled the NIJ and NIIC with hydrography and velocity. This affords us the opportunity to compare the equatorward transport of overflow water in the NIJ with the poleward transport of Atlantic water in the NIIC. One of the arguments for the overturning loop in the Iceland Sea is that there is an approximate mass balance between these two flows (Våge et al. 2011), although this is not a requirement. Using the yearlong data set from the Kögur mooring array, Harden et al. (2016) estimated that the mean transport of overflow water in the NIJ is $1.00 \mathrm{~Sv}$. By comparison, using 16 years of mooring data on the Iceland shelf (roughly $85 \mathrm{~km}$ to the northeast of the Kögur line), Jónsson and Valdimarsson (2012) calculated a transport of Atlantic water of $0.88 \mathrm{~Sv}$ in the NIIC. It should be noted that the latter estimate was based on only three moorings with limited vertical coverage. Also, Jónsson and Valdimarsson (2012) used a water mass end member technique to isolate the transport of "pure" Atlantic water within the NIIC, which is what their value represents. In particular, they calculated the percent transport associated with an Atlantic water end member in Denmark Strait (see later in this section for details).

For each of our vertical sections, we calculated the volume transport of the NIJ and the NIIC (Fig. 5) along with an estimate of the error (based on the uncertainty in velocity; see Våge et al. 2013). The NIJ value represents water denser than $27.8 \mathrm{~kg} \mathrm{~m}^{-3}$, which is commonly taken as the upper limit of DSOW (Dickson and Brown 1994). The average NIJ transport over all eight occupations is $1.23 \pm 0.32 \mathrm{~Sv}$, which is a bit more than the yearlong average of Harden et al. (2016), but within the error bar. The average NIIC transport (for the seven occupations that sampled the current) is $3.07 \pm 0.29 \mathrm{~Sv}$. This is more than twice the transport of the NIJ and seemingly calls into the question the notion of a mass balance for the Iceland Sea overturning loop. However, there are several caveats that we now consider that impact our estimates.

The first thing to note is that the NIIC advects a small amount overflow water northward through Denmark Strait. Averaged over all occupations, the value is $0.19 \mathrm{~Sv}$. This contribution should be discounted when considering the warm-to-cold conversion in the Iceland Sea. Second, the NIIC transport during February 2011 was anomalously large. In particular, it is more than 2 standard deviations larger than the mean, in contrast to the other values which all fall within 0.15 of 1 standard deviation. It is also more than 2.5 times greater than the next largest value (Fig. 5). As such, it is reasonable to discard this value as nonrepresentative. Taking both of these factors into account, the mean NIIC transport reduces to $2.07 \pm 0.27 \mathrm{~Sv}$, which is closer to the equatorward transport of the NIJ.

To be consistent with Jónsson and Valdimarsson (2012), we computed the transport of pure Atlantic water within the NIIC in each of our sections. Following their study, for the 
(a) North Icelandic Jet

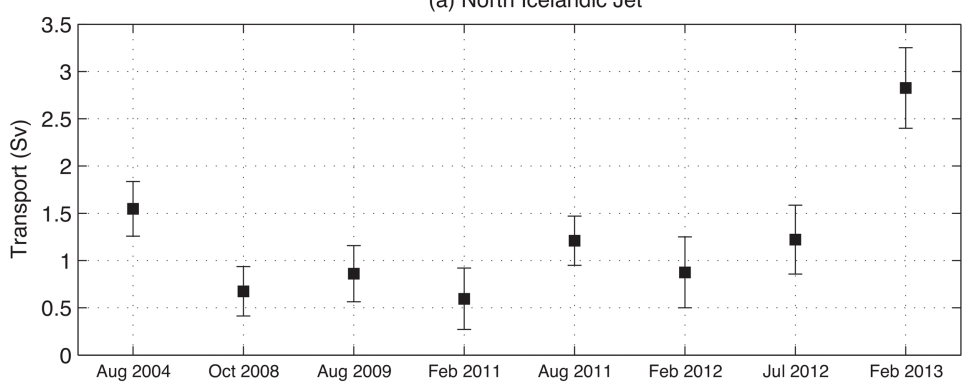

(b) North Icelandic Irminger Current

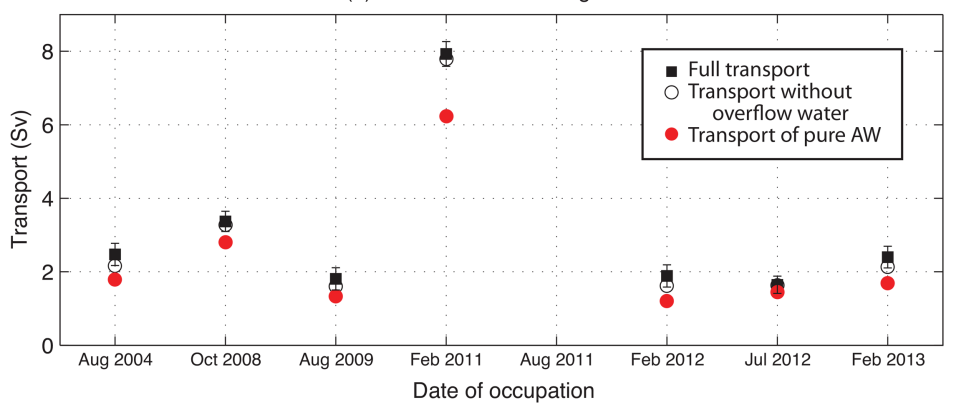

Figure 5. Volume transport (solid black squares) of the North Icelandic Jet (NIJ) (a) and North Icelandic Irminger Current (NIIC) (b) for each of the Kögur transects (see legend of Fig. 2). The standard deviations are indicated. The NIJ transport is equatorward, and the NIIC transport is poleward. Note that there is no value for the NIIC for the August 2011 crossing. The open circles in panel (b) are the transport of the NIIC minus the overflow contribution. The red circles in panel (b) are the transport of pure Atlantic water (AW) (see text).

Atlantic water end member we used a station on the Iceland shelf at the Látrabjarg transect near the Denmark Strait sill (station \#6 along the transect; see Jónsson and Valdimarsson 2012). This captures the warm and salty water when it first enters the Nordic Seas. For the polar water end member, we again followed the earlier study and used the station on the seaward end of the Kögur transect. Hence, for each occupation, we used the westernmost station on our Kögur transect along with station \#6 from the Látrabjarg transect (which was occupied just days before the Kögur section). As such, we were able to employ time-varying end members for our calculation.

To compute the percentage of Atlantic water in the NIIC for our seven realizations, we plotted the two end members in temperature-salinity $(T / S)$ space for each transect in addition to all of the data points from the stations across the current. Next, at each $10 \mathrm{~m}$ increment in depth, we drew a mixing line between the Atlantic water and polar water end members and computed the distance of each transect grid point to these end points. The percentage of the Atlantic water was taken to be inversely proportional to the 
distance from the grid point in question to the Atlantic water end member. Finally, vertical sections of Atlantic water percentage were constructed for each of the occupations, and this was multiplied by the corresponding vertical sections of northward transport to obtain the volume flux of pure Atlantic water.

The results of this calculation are shown in Figure 5 (red circles). One sees that, aside from the anomalous occupation in February 2011, there is relatively little non-Atlantic water transported by the NIIC at this location. Nonetheless, taking this into account (and discounting the February 2011 value), the NIIC transport is reduced to $1.71 \pm 0.22 \mathrm{~Sv}$. A final thing to keep in mind is that the NIJ advects some amount of water lighter than 27.8 $\mathrm{kg} \mathrm{m}^{-3}$ (Fig. 4). Hence a fairer comparison between the inflow and outflow is to consider the water in the NIJ that is denser than the pure Atlantic water in the NIIC, as opposed to using the $27.8 \mathrm{~kg} \mathrm{~m}^{-3}$ isopycnal as the upper bound. (The average bound in question for the NIIC is $27.74 \mathrm{~kg} \mathrm{~m}^{-3}$ over all of the occupations.) When this is done, the corresponding inflow and outflow transports are $1.71 \pm 0.22 \mathrm{~Sv}$ and $1.29 \pm 0.33 \mathrm{~Sv}$, respectively. This suggests that the two are in fact relatively close to balancing each other, especially in light of the uncertainty in our transport calculations.

\section{d. Volume transport in $T / S$ space}

It is of interest to break down the mean volume transport of the NIJ into $T / S$ classes. This was done by dividing the $T / S$ plane into increments of $0.2^{\circ} \mathrm{C}$ in temperature and 0.01 in salinity and then computing the volume transport of the NIJ water within each bin. This reveals that most of the dense overflow advected by the current is confined to a relatively small region in $T / S$ space (Fig. 6). The majority of the volume flux is denser than 27.9 $\mathrm{kg} \mathrm{m}^{-3}$ (see also Fig. 3) and is contained in a narrow limb that extends to colder and saltier values. Within this limb there is a pronounced mode defined by a temperature range of $-0.4^{\circ} \mathrm{C}$ to $0^{\circ} \mathrm{C}$ and salinity range of 34.90 to 34.91 . This small $T / S$ class transports $0.32 \mathrm{~Sv}$, which is approximately $25 \%$ of the total transport of the NIJ. The location of this volumetric transport mode in geographic space is shown in Figure 3 (denoted by the white line). Hence, the deep portion of the NIJ accounts for most of the transport in $T / S$ space that feeds the Denmark Strait overflow.

\section{Pathway of the NIJ}

As seen in the mean vertical sections for the Kögur line (Fig. 3), on average the NIJ is situated immediately adjacent to the NIIC. It turns out, however, that this is not always the case-either at this spot or other locations along the NIJ's pathway (keep in mind the three Kögur winter realizations with an offshore NIJ core). We now investigate more carefully the relative locations of the NIJ and NIIC along the full path of the NIJ as it progresses along the north slope of Iceland toward Denmark Strait. For this part of the analysis, we make use of the transects occupied on two of the cruises: fall 2008 and summer 2009 (see Fig. 2 and Table 1). 


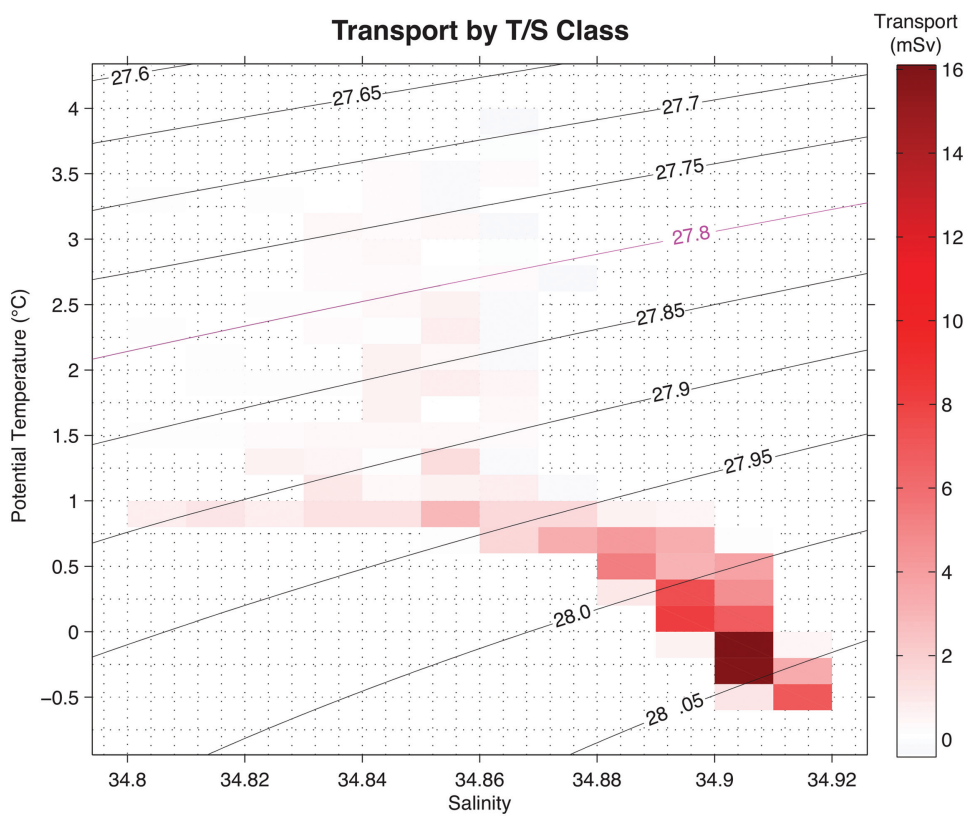

Figure 6. Volume transport of the North Icelandic Jet (color, $\mathrm{mSv}$ ) as function of potential temperature and salinity. The contours are potential density $\left(\mathrm{kg} \mathrm{m}^{-3}\right)$. The density corresponding to the top of the overflow water layer (27.8) is highlighted. $T / S$, temperature-salinity.

Let us first examine a realization in which the two currents are situated side by side (Fig. 7). This transect was occupied just to the west of the Kolbeinsey Ridge, and one sees that the warm and salty Atlantic water is present across the entire Iceland shelf (Fig. $7 \mathrm{~b}$ and c). In the vicinity of the shelf break there is a pronounced density front extending to approximately 400 $\mathrm{m}$ depth. Note that the sense of the front (denser to lighter progressing onshore) is dictated by the lateral temperature gradient (colder to warmer progressing onshore). Notably, this front supports both the upper portion of the NIJ and the deeper portion of the NIIC (Fig. 7d). That is, the equatorward flow of the NIJ increases with depth, whereas the poleward flow of the NIIC decreases with depth (and reverses below $\sim 250 \mathrm{~m} \mathrm{depth}$ ). The magnitude of the lateral density gradient is shown in Figure 7(e), revealing that it is strongest within the boundaries of the NIJ.

The next realization that we consider was occupied at the Kögur line (Fig. 8). Contrary to the previous example, the Atlantic water does not extend all the way to the Iceland shelf break (Fig. 8b and c). Instead, the density front associated with this warm and salty water is located on the midshelf, and it supports the NIIC alone (the isopycnals are flat across the shelf break; Fig. 8d). Farther offshore, in the vicinity of the NIJ, there is a second density front. It has the same sense as the NIIC front (denser to lighter progressing onshore because of the lateral temperature gradient). As with the previous realization, this front is associated 

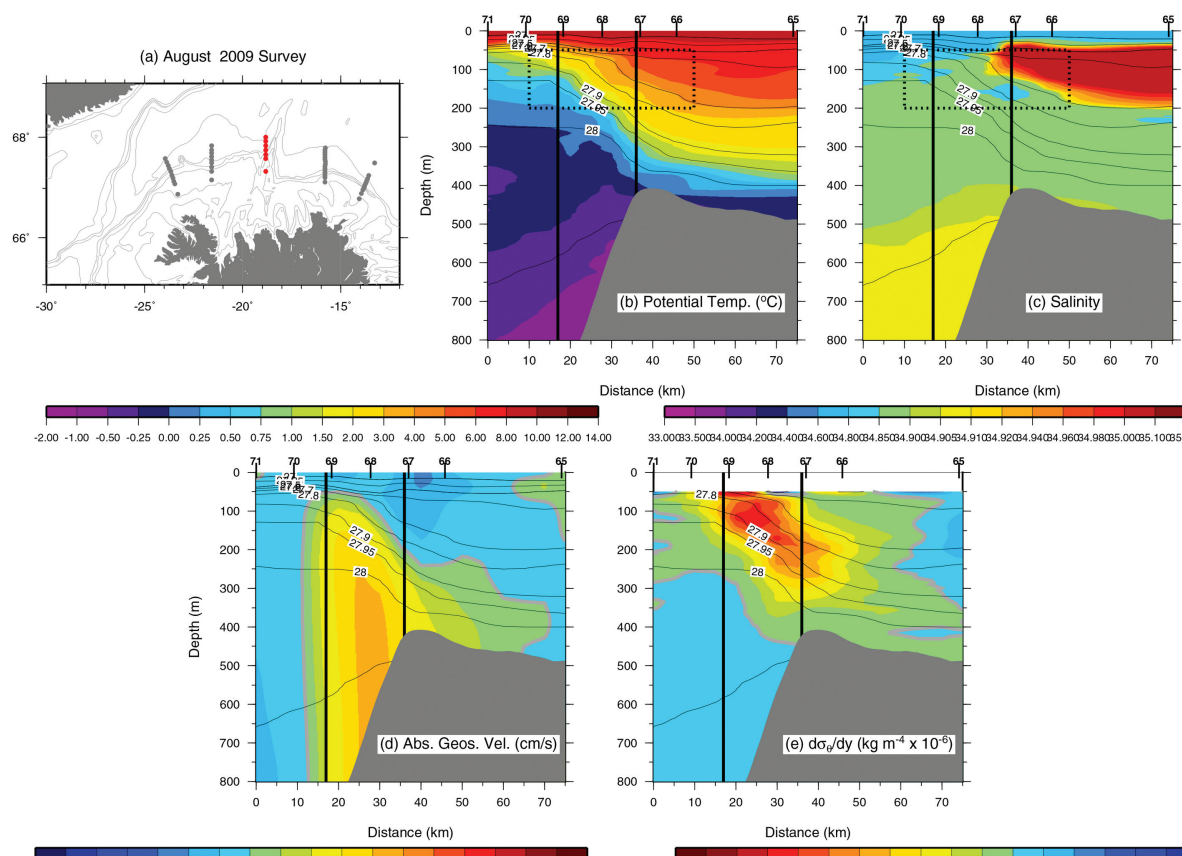

Distance $(\mathrm{km})$

Distance $(\mathrm{km})$

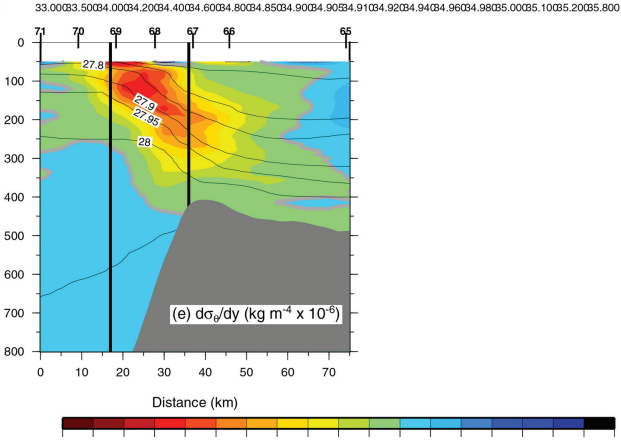

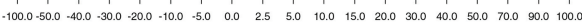

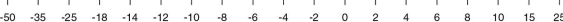

Figure 7. Vertical sections of properties for transect $S$ when the Atlantic water extends to the shelf break. (a) Location of the transect (red symbols). (b) Potential temperature (color, ${ }^{\circ} \mathrm{C}$ ) overlain by potential density (contours, $\mathrm{kg} \mathrm{m}^{-3}$ ). (c) Salinity (color). (d) Absolute geostrophic velocity (color, $\mathrm{cm} \mathrm{s}^{-1}$ ), where positive velocities are equatorward. (e) Lateral density gradient. The station numbers are marked at the top. The dashed box in panel (b) denotes the region over which the characteristics of the hydrographic front were determined (see text). The two black vertical lines mark the lateral limits of the North Icelandic Jet.

with enhanced equatorward flow of the NIJ with depth. Note also that there is a small amount of poleward flow in the surface layer immediately inshore of the NIJ (centered at $x=30$ km; Fig. 8d). The same density front is responsible for weakening this flow with depth (and reversing it below $50 \mathrm{~m}$ ). Hence, in both realizations there is a density front dictating the vertical structure of the NIJ as well as poleward flow next to the NIJ-in the first case the poleward flow is the NIIC, and in the second case it is not. In both examples the density front shows up clearly in the vertical section of lateral density gradient (compare Figs. 7e and $8 \mathrm{e})$.

Going through all 11 realizations for the two cruises, we find that in roughly half the cases the NIJ is located adjacent to the NIIC. In the remaining cases, the NIJ is next to poleward flow that is not the NIIC. In the former scenario, a single density front is associated with the NIJ and NIIC (similar to Fig. 7). In the latter scenario, the density front is linked to the NIJ and to the poleward flow that is distinct from the NIIC (similar to Fig. 8). (We 

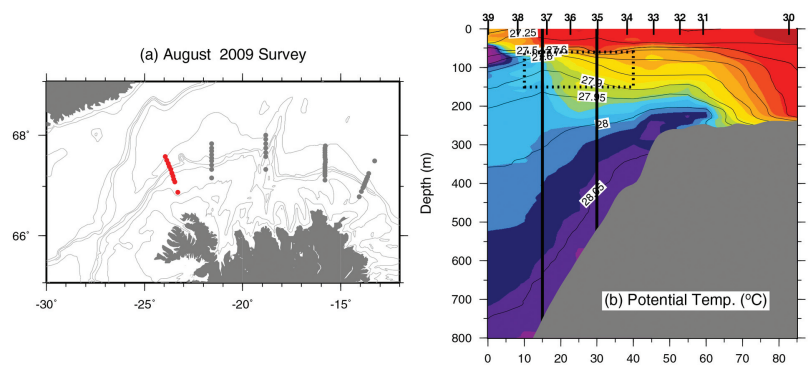

Distance $(\mathrm{km})$

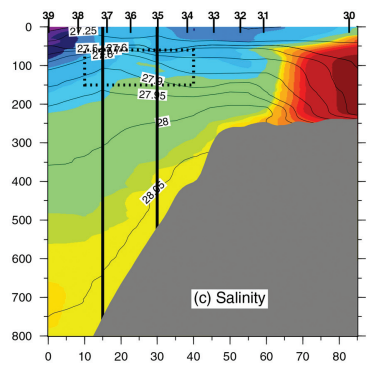

Distance $(\mathrm{km})$

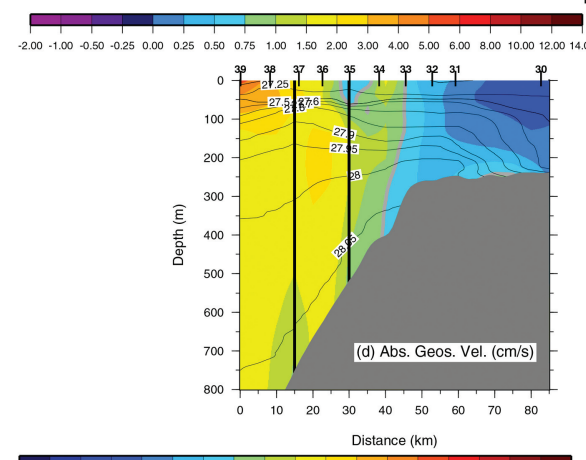

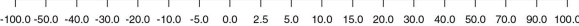

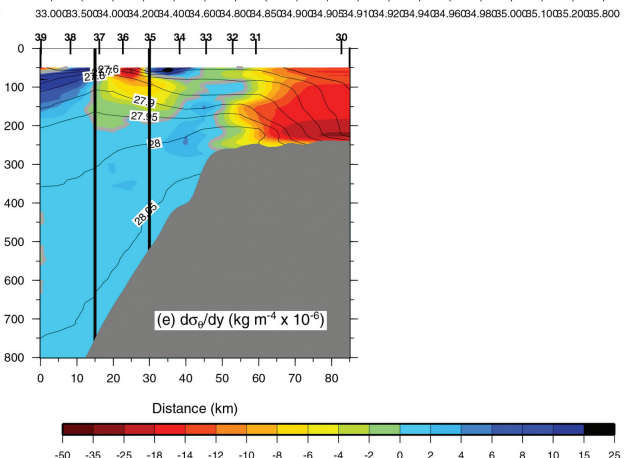

Figure 8. Same as Figure 7 except for transect $\mathrm{K}$ when the Atlantic water did not reach the shelf break.

note that one of the transects had a double NIJ core where the inner branch was next to the NIIC.) A natural question to ask is, are there any trends associated with these two scenarios?

Using the vertical sections for each occupation (i.e., the same set of plots as shown in Figs. 7 and 8 for all of the transects), we tabulated the strength of the density front near the NIJ, the magnitude of the poleward flow inshore of the NIJ, and the value of the salinity inshore of the density front (averaged over the depth range of the front). These are plotted as a function of realization in Figure 9, which demonstrates that all of these variables vary in phase with each other. In particular, when the density front (plotted here as baroclinic shear) is strong, the poleward flow next to the NIJ is strong, and the salinity inshore of the front is large. The opposite is true for the other realizations. In Figure 9, we have marked the cases when the salinity value is indicative of the Atlantic water. It is thus clear that there are six instances when the NIJ is immediately adjacent to the NIIC: strong poleward flow, high salinity, and strong baroclinic shear. By contrast, there are five cases when the NIJ resides next to a much weaker poleward flow with less baroclinic shear and lower salinity inshore of the front. The average poleward flow for the NIIC cases is $29 \mathrm{~cm} \mathrm{~s}^{-1}$ compared with $4 \mathrm{~cm} \mathrm{~s}^{-1}$ for the other realizations. 

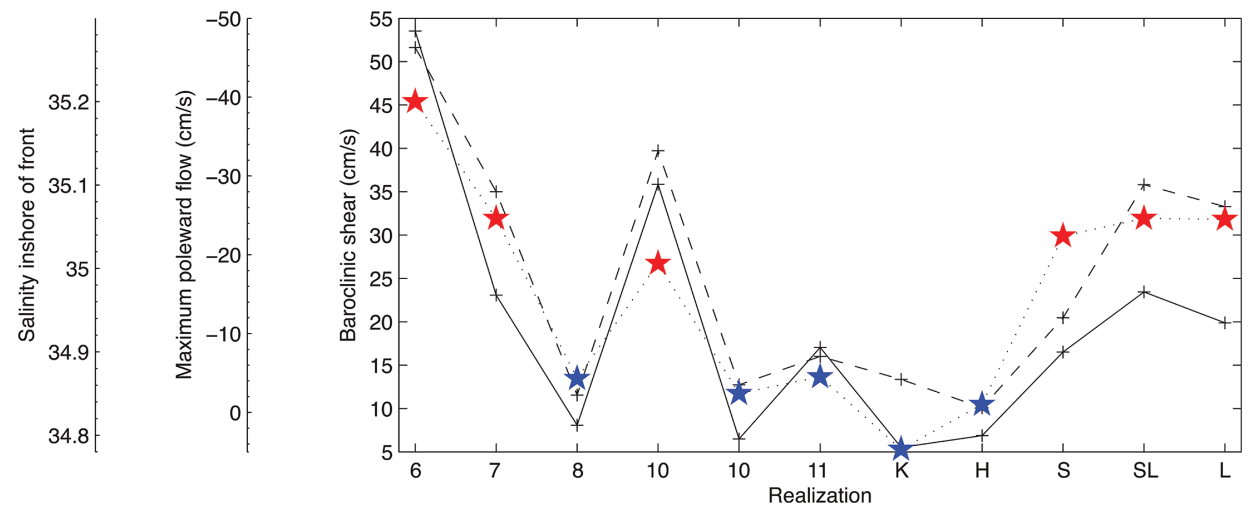

Figure 9. Strength of the density front near the North Icelandic Jet (NIJ; plotted as baroclinic shear over the vertical extent of the front, solid line), value of the poleward flow inshore of the NIJ (dashed line), and the value of the salinity inshore of the density front (dotted line). Those realizations where the inshore salinity value was indicative of the Atlantic water are denoted by red stars. The other cases (when the water was not Atlantic water) are denoted by blue stars. The transect labels are indicated (see Fig. 2). Note that realization 10 had two NIJ cores.

Hence, in all cases the NIJ appears to be coupled to a poleward current. Why is it that only some of the time this current is the NIIC? When this is not the case, what is the nature of the poleward flow? Although we are not able to provide definitive answers to these questions, we can shed light on both issues. In Våge et al.'s (2011) study of the NIJ, they determined that the current generally follows the $650 \mathrm{~m}$ isobath as it flows toward Denmark Strait (whose sill depth is also $650 \mathrm{~m}$ ). The NIIC, on the other hand, is confined to the Iceland shelf and shelf break (although it can meander laterally; Jónsson and Valdimarsson 2005). A reasonable choice for the mean isobath of the NIIC is $350 \mathrm{~m}$, based on the MRI data set.

Comparing these two isobaths reveals that the lateral distance between them varies substantially along the north slope of Iceland (Fig. 10). Near Denmark Strait, as well as in the northeast part of the domain, the continental slope is fairly steep and the two isobaths are close to each other (average separation $\sim 10 \mathrm{~km}$ ). In the middle part of the domain, the slope is more gentle and the isobaths are farther apart (average separation $\sim 30 \mathrm{~km}$ ). For the six transects in which the NIJ was found immediately adjacent to the NIIC, the average isobath separation was $<15 \mathrm{~km}$. By contrast, for the five transects where the NIJ was separated from the NIIC, the average separation was $>30 \mathrm{~km}$. The simple conclusion is that the proximity of the NIJ to the shelf break dictates to first order if the current shares a common front with the NIIC. We hasten to add, however, that this is not the only criterion. For example, at section $\mathrm{H}$ near $21.6^{\circ} \mathrm{W}$ (which is also section 10; Fig. 2), both scenarios were observed. This is likely because of the ability of the NIIC to occasionally meander seaward, closer to the location of the NIJ. Such meandering of the NIIC is evident in drifter data (Valdimarsson and Malmberg 1999). 


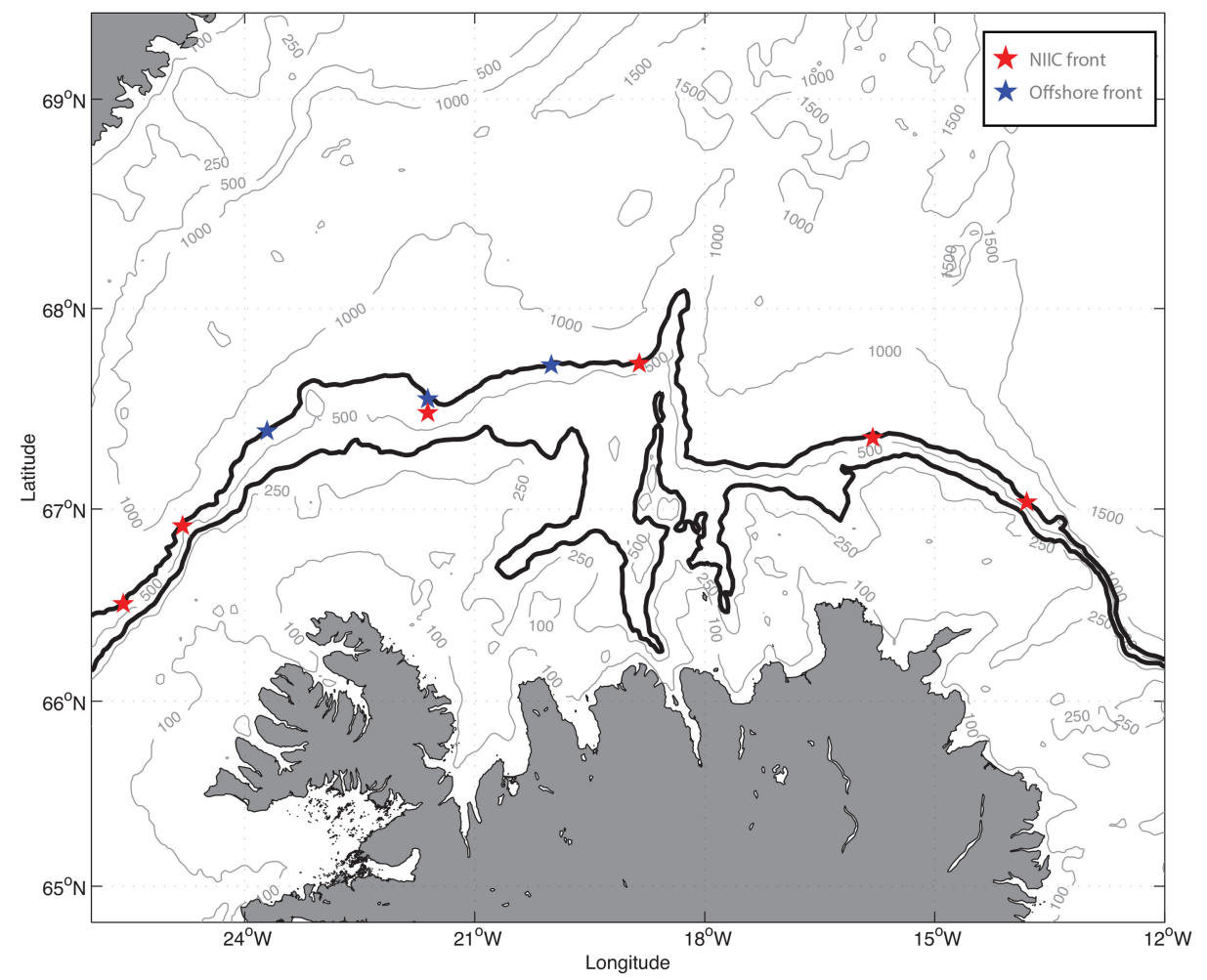

Figure 10. Bathymetric map highlighting the isobath typically associated with the North Icelandic Jet (NIJ; $650 \mathrm{~m}$ ) and that typically associated with the North Icelandic Irminger Current (NIIC; 350 $\mathrm{m})$. The realizations where the NIJ was situated next to the Atlantic water are denoted by the red stars, and the other cases (non-Atlantic water) are denoted by the blue stars (see Fig. 9). Note that two of the latter realizations corresponded to the same geographic location as other occupations (which is why there are only three blue stars in the figure vs. five blue stars in Fig. 9).

We examined more closely the characteristics of the hydrographic front for the five cases when the NIJ was not linked to the NIIC. The cross-stream variation in temperature, salinity, and density was computed over a representative region encompassing the front (see the dashed box in Figs. 7 and 8; a similar box was constructed for each of the five transects). The results of this calculation are shown in Figure 11. As was noted earlier, in each instance the sense of the density change is the same: denser offshore to lighter onshore, although the magnitude of the jump varies substantially (the vertical scales are the same in Fig. 11). Notably, although the temperature always goes from colder to warmer across the front, there is no set pattern for salinity. In two of the cases, the salinity increases going onshore; in two other cases, it decreases going onshore; and in the last instance, there is very little change across the front. As such, the density change is always dictated by the lateral 

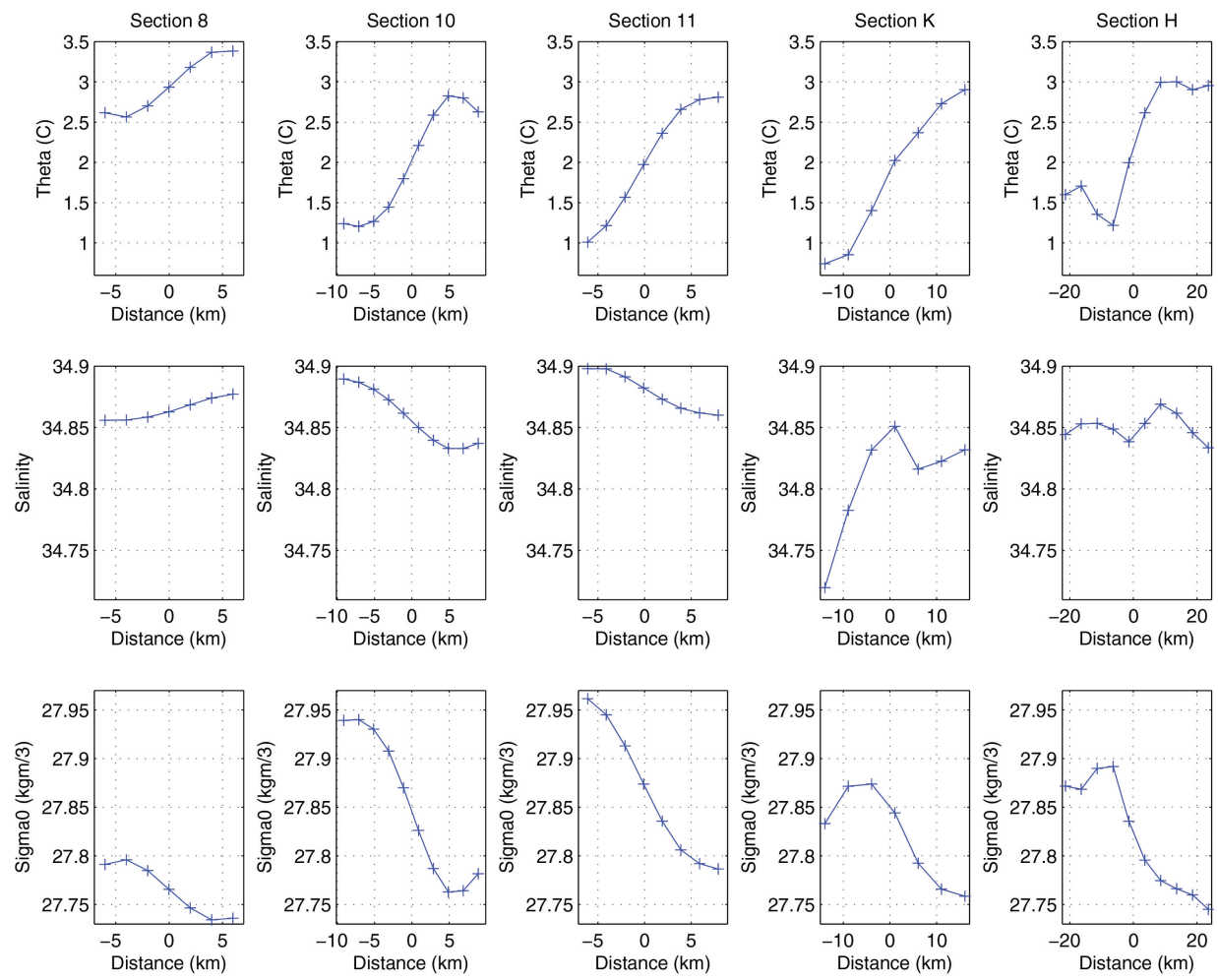

Figure 11. Characteristics of the hydrographic front for the five cases when the North Icelandic Jet was situated next to water that was not Atlantic water. See Figures 7 and 8 for examples of the region over which the frontal characteristics were computed. The top row is potential temperature, the middle row is salinity, and the bottom row is potential density.

temperature gradient. At this point, it is unclear how this offshore temperature front gets established, but it seems to be a ubiquitous feature when the NIJ is found seaward of the NIIC.

Further work is required to understand the dynamics governing the two NIJ scenarios and the role of the associated hydrographic front. However, it is reasonable to assume that when the NIIC is immediately adjacent to the NIJ (i.e., when they share a common front), the two flows are dynamically linked. For instance, the stronger cross-frontal density gradient in this case (Fig. 9) may alter the stability characteristics of the flow leading to enhanced baroclinic instability (Isachsen 2011). The steeper topography associated with these conditions also tends to make the flow more baroclinically unstable (Spall 2010; Isachsen 2015). This in turn will impact the cross-stream eddy fluxes of heat and salt from the NIIC into the interior, which is an important component of the local overturning cell in the Iceland Sea (Våge et al. 2011). It suggests that there may be localized regions of enhanced exchange. 


\section{Interannual variability}

\section{a. The NIJ water mass}

As seen in Table 1, the eight occupations of the NIJ at the Kögur line were obtained over a time span of 9 years. It is of interest then to determine if there were interannual variations in the hydrographic properties of the overflow water mass advected by the current. This is most effectively accomplished by working in density space. This is because vertical heaving of density surfaces due to mesoscale variability often makes it difficult to detect changes in water masses when considering vertical sections in depth space (e.g., a hydrographic anomaly resulting from differencing two sections can be mainly attributable to isopycnal displacement). As such, we constructed sections where the vertical coordinate was density instead of depth. This was done as follows. Using the data for all of the occupations, we computed a single average density profile (which was low passed to remove any irregularities). This was used to make a lookup table, and for each CTD profile, the density value was replaced by the depth corresponding to the average profile. This variable is referred to as scaled depth, $z^{\prime}$. We then constructed vertical sections of temperature and salinity versus $z^{\prime}$.

The sections of temperature in this coordinate system for the eight crossings (Fig. 12) unambiguously reveal various aspects of the variation in the water masses (note that the isopycnals are flat in this coordinate frame). For example, the seasonal densification of the Atlantic water in the NIIC is apparent by the outcropping of the surface isopycnals (i.e., no data for $z^{\prime}$ shallower than about $100 \mathrm{~m}$ for the three February occupations). Note also the variation in the deepest isopycnals. For example, the 2004 and August 2011 crossings have data extending close to $z^{\prime}=1,000 \mathrm{~m}$, whereas the 2009 and 2013 occupations have very little data below $z^{\prime}=800 \mathrm{~m}$. This near-bottom variability is likely because of mesoscale heaving of density surfaces, which in this coordinate frame simply shows up as different extents of data coverage.

It is clear in the vertical sections of Figure 12 that the deep portion of the NIJ has warmed over the 9 years of data coverage. For instance, the density range of $28.04-28.05 \mathrm{~kg} \mathrm{~m}^{-3}$ has warmed by more than $0.15^{\circ} \mathrm{C}$. Corresponding to this, the water has become saltier (which it must in order to maintain the same density). To quantify this, we computed the average temperature and salinity for the density range of $28.035-28.06 \mathrm{~kg} \mathrm{~m}^{-3}$ in the NIJ (using the velocity sections to define the lateral bounds of the current). This is the densest portion of the overflow water transported by the NIJ, which is not found in either of the branches of the EGC (Våge et al. 2013). The resulting time series (Fig. 13) shows the marked warming and salinification of this water mass over the last few years of the record.

To put this into broader context, we used the historical hydrographic data set of the Nordic Seas employed by Våge et al. (2013). This climatology encompasses the period 1980 to the present and uses data from a number of sources, including CTD stations from MRI, the International Council for the Exploration of the Seas, the World Ocean Database, and the Norwegian Iceland Seas Experiment database (Nilsen et al. 2008). The reader is referred 

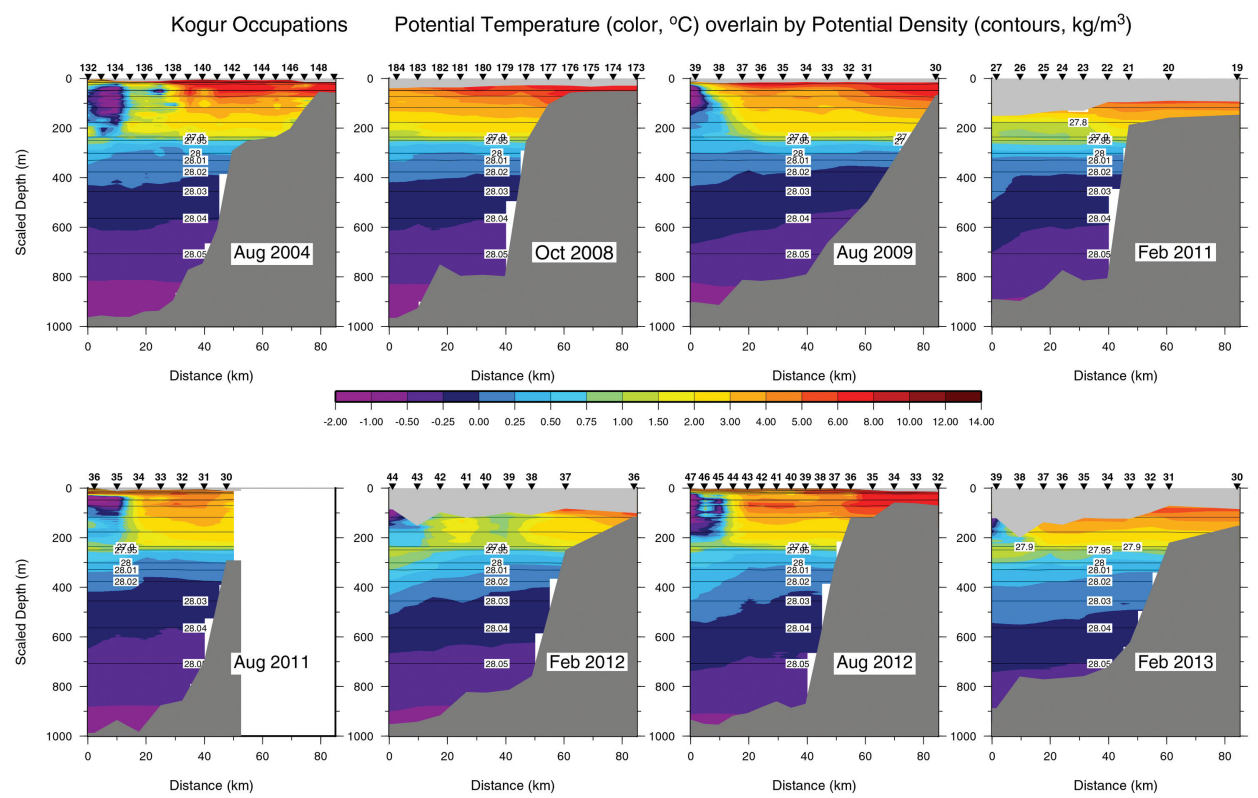

Figure 12. Vertical sections of potential temperature (color, ${ }^{\circ} \mathrm{C}$ ) overlain by potential density (contours, $\mathrm{kg} \mathrm{m}^{-3}$ ) for the eight Kögur transects. The vertical coordinate is $z^{\prime}$, which is used to construct the sections in density space (see text). The station numbers are marked along the top for each transect. The dark-gray shading indicates bottom outcropping, and the light-gray shading indicates surface outcropping.

to Våge et al. (2013) for details. Over the years, MRI has regularly occupied the Kögur section, nominally four times a year (February, May, August, and November). Because the occupations do not include velocity measurements, we are unable to isolate the water within the NIJ. However, because it has been established that the current is centered at the $650 \mathrm{~m}$ isobath, we can assume that it is generally confined between the $400 \mathrm{~m}$ and $800 \mathrm{~m}$ isobaths (see Fig. 3). Accordingly, we constructed a time series of the water properties for the dense portion of the NIJ (28.035-28.06 $\mathrm{kg} \mathrm{m}^{-3}$, same as previously) by averaging the stations between these two isobaths for the collection of MRI Kögur transects. This was done for the time period 1990-2013.

As seen in Figure 14, this proxy time series agrees well with the more precisely determined values for the eight occupations with velocity considered in this study (the uncertainties in the proxy record are shown in Fig. 15). The longer-term record reveals that the properties of the dense water in the NIJ have varied quite substantially over the past 25 years. In particular, there was a period of colder and fresher overflow water from the mid-1990s to the early 2000s. Following this there was an abrupt transition to warmer and saltier values and then a more gentle increase until very recently (after 2012) when rapid warming and salinification occurred again — to levels not attained during the previous 25 years. We now 

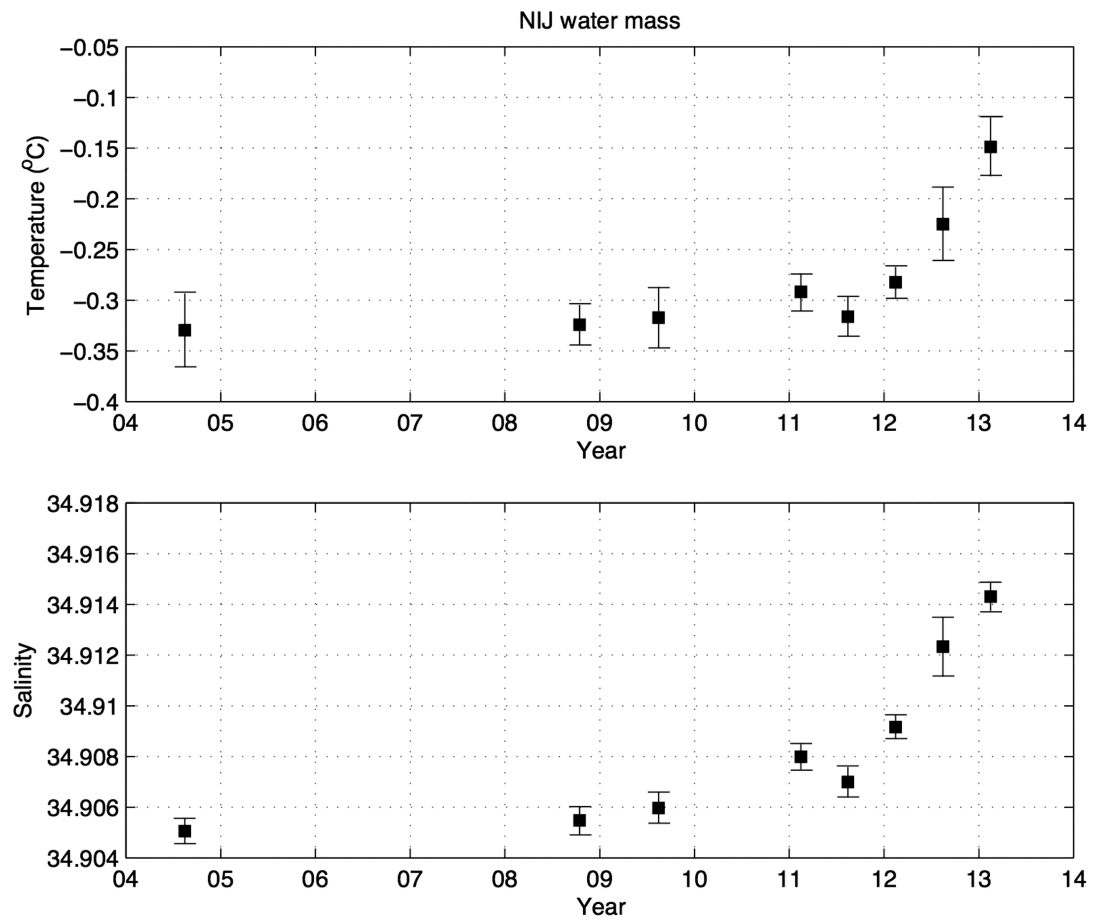

Figure 13. Characteristics of the dense water, averaged over the potential density interval 28.035$28.06 \mathrm{~kg} \mathrm{~m}^{-3}$, transported by the North Icelandic Jet (NIJ) for the eight Kögur transects plotted by year. The top panel is potential temperature, and the bottom panel is salinity. The standard deviations are indicated.

relate this interannual variability at the Kögur line to the observed changes in the dense water flowing over the Denmark Strait sill.

\section{b. Overflow water passing through Denmark Strait}

In a recent study, Mastropole et al. (2017) used a collection of hydrographic sections occupied in the vicinity of the Denmark Strait sill between 1990 and 2012 to investigate the characteristics of the overflow water entering the Irminger Sea. Of their 111 realizations, approximately $40 \%$ contained a "bolus" of overflow water at the sill. These are weakly stratified lenses of dense water that occupy a fairly large portion of the deep trough in Denmark Strait as they pass through. The intermittent presence of these features in the strait has been recognized for decades (e.g., Cooper 1955), but Mastropole et al. (2017) were the first to systematically characterize their $T / S$ properties. Using an objective definition of a bolus, they found that these features constitute the coldest and saltiest component of DSOW and are composed mainly of Arctic-origin water. As such, it is likely that the water within these features originates from the NIJ. 

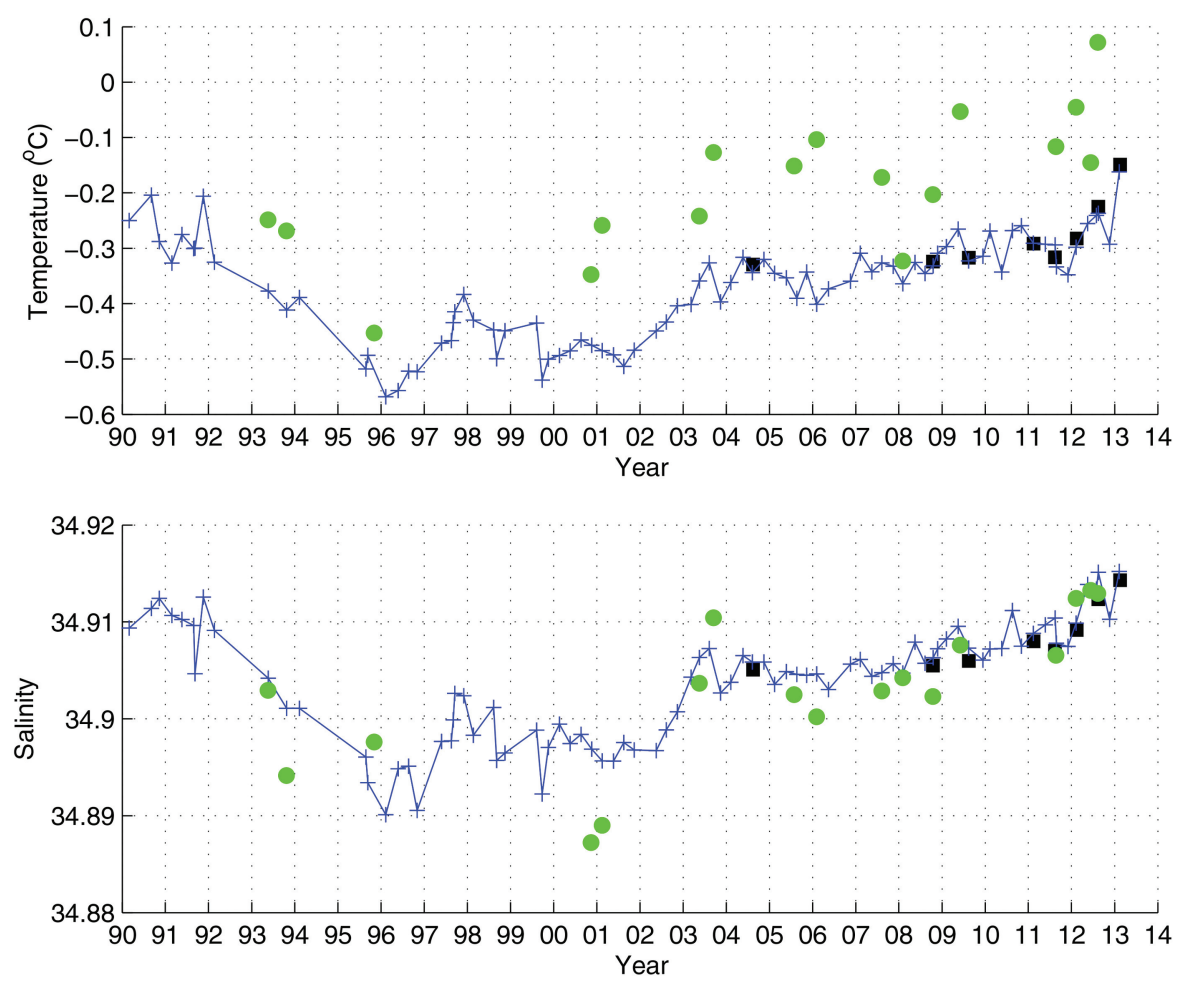

Figure 14. Time series of potential temperature (top panel) and salinity (bottom panel) of the dense North Icelandic Jet water at the Kögur transect constructed using the historical data (blue lines). The corresponding values for the eight realizations considered in this study are denoted by the black squares (same as Fig. 13). The green circles are the values of the dense boluses observed at the Denmark Strait sill by Mastropole et al. (2017).

Although Mastropole et al. (2017) found no discernable seasonal signal in the bolus hydrographic properties, they revealed that the properties changed over the length of the 25-year record. This motivates us to compare the interannual variability of the NIJ water determined previously with that found in the boluses measured at the sill. To be consistent, we considered only the boluses with an average density greater than $28.035 \mathrm{~kg} \mathrm{~m}^{-3}$ (i.e., the upper limit of the density range used previously for the NIJ). Comparing the resulting bolus properties with those of the NIJ water at the Kögur line, we find that there is a clear relationship between the two (Fig. 14). Consider first the salinity. The low frequency change in the salinity of the boluses tracks that seen in the upstream NIJ, including the fresh period from the mid-1990s to the early 2000s and the salinification that has occurred since. Overall, the bolus values are a bit fresher; the mean offset between the two time series is 0.002 (which is near the accuracy of the CTD salinity measurements). 


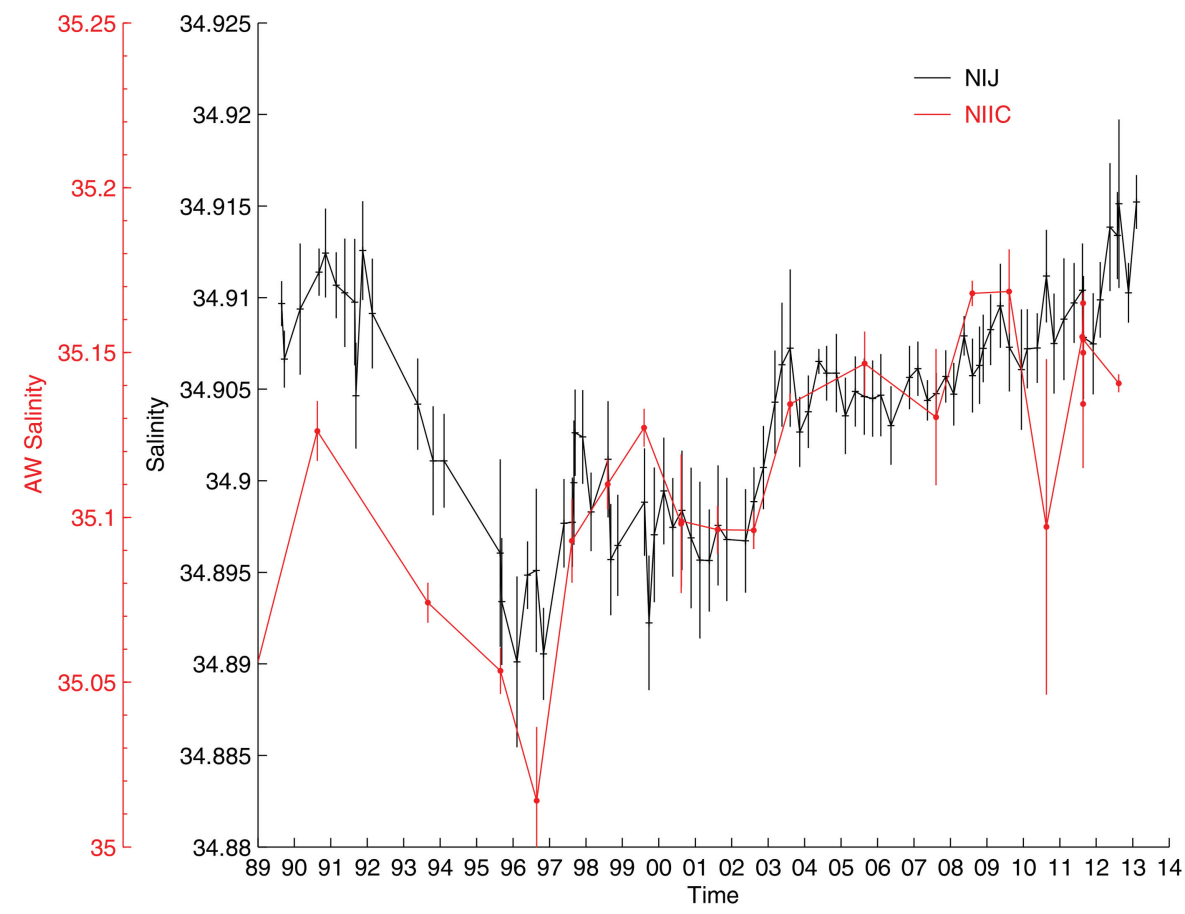

Figure 15. Time series of salinity of the dense North Icelandic Jet (NIJ) water at the Kögur transect from Figure 14 (black line) compared with that of the Atlantic water (AW) flowing northward through Denmark (red line). Note the change in salinity scales for the two curves. The standard deviations are indicated. NIIC, North Icelandic Irminger Current.

By contrast, the temperature of the boluses is significantly warmer than that measured upstream. However, the general trends are again the same: cooling early in the record, then a warming that has continued until the end of the time series. The mean offset between the two records is $0.18^{\circ} \mathrm{C}$. Thus, as the dense water travels the $200 \mathrm{~km}$ distance from the Kögur line to the Denmark Strait sill, it mixes with surrounding water and becomes warmer and slightly fresher-and hence less dense (consistent with the results of Jonsson and Valdimarsson [2004]). In light of Figure 3, this makes sense, because the ambient water offshore of the NIJ is warmer and fresher. Note that there is more scatter in the bolus properties than for the NIJ water upstream. This is likely because of the turbulent nature of the mixing, the strength of which undoubtedly varies in time and space.

\section{Subtropical inflow versus dense outflow}

We now seek to determine if there is relationship between the inflowing Atlantic water in the NIIC and the dense outflow in the NIJ. If there is a local overturning loop in the Iceland Sea-which is consistent with the mass budget presented previously-then one 
would expect a connection between the interannual variability of the inflow and that of the outflow. To construct a time series of the inflow properties, we used station 6 on the Látrabjarg (i.e., the Atlantic water end member used previously). Because of the large seasonal signal in temperature and salinity, we considered the summer occupations only (i.e., before any transformation takes place). We then isolated the Atlantic water signal by averaging within the density range $27.5-27.6 \mathrm{~kg} \mathrm{~m}^{-3}$ (see the mean summer salinity section of Fig. 4).

The resulting time series of inflowing salinity shows a clear relationship with the outflowing salinity of the NIJ (Fig. 15). Strikingly, the two curves are approximately in phase with each other (the sparsity of the measurements makes it impossible to determine a phase lag within \pm 1 year). Based on this, one possible conclusion is that the overturning loop operates on a short timescale; that is, the inflowing Atlantic water is transformed and exported within a year (or slightly longer). This seems highly unlikely if the transformation takes place within the Iceland Sea gyre, because the water there is trapped to a large degree within the closed streamlines (i.e., within closed dynamic height contours; Våge et al. 2013; see also Fig. 16). However, using a combination of hydrographic profiles and Argo float data, Våge et al. (2015) demonstrated that the deepest and densest winter mixed layers in the Iceland Sea occur outside of the gyre to the northwest (Fig. 16), where there is no such trapping. This has been confirmed recently using glider data (K. Våge, personal communication, 2016). This raises the possibility of more rapid overturning and exchange in that region, which feeds the densest part of the NIJ. We now consider several factors that address the likelihood of this.

There are two components of the inflowing and outflowing salinity time series in Figure 15 that need to be addressed. First, the mean salinity is modified from approximately 35.1 in the inflowing NIIC to approximately 34.9 in the outflowing NIJ. Second, although both time series show the same phase with respect to the low frequency variability, the amplitude of the fluctuations in the inflowing Atlantic water are roughly an order of magnitude larger than those of the outflowing NIJ. Keep in mind that we are considering the densest portion of the NIJ (potential density between 28.035 and $28.06 \mathrm{~kg} \mathrm{~m}^{-3}$ ), which in the mean transports $0.45 \mathrm{~Sv}$ over the eight Kögur occupations. Therefore, we assume that roughly half of the $\mathrm{O}(1 \mathrm{~Sv}) \mathrm{NIJ}$ arises from convection in the northwest Iceland Sea, ${ }^{1}$ while the other (lighter) half stems from transformation elsewhere. It is worth noting that in Våge et al.'s (2011) idealized model the downwelling near the Iceland slope does not account for the full NIJ transport, and other numerical models suggest that the NIJ is also fed from remote regions (Köhl et al. 2007; Yang and Pratt 2014).

If approximately $0.5 \mathrm{~Sv}$ of the NIJ originates from the northwest Iceland Sea, it would take approximately $100 \mathrm{mSv}$ of freshwater, relative to 34.9 , to mix with the inflowing salinity of 35.1 to produce an outflow salinity of 34.9 . There are three primary sources of freshwater

1. It is likely that there is a contribution to the densest portion of the NIJ from the Greenland Sea as well (Vage et al. 2015). 


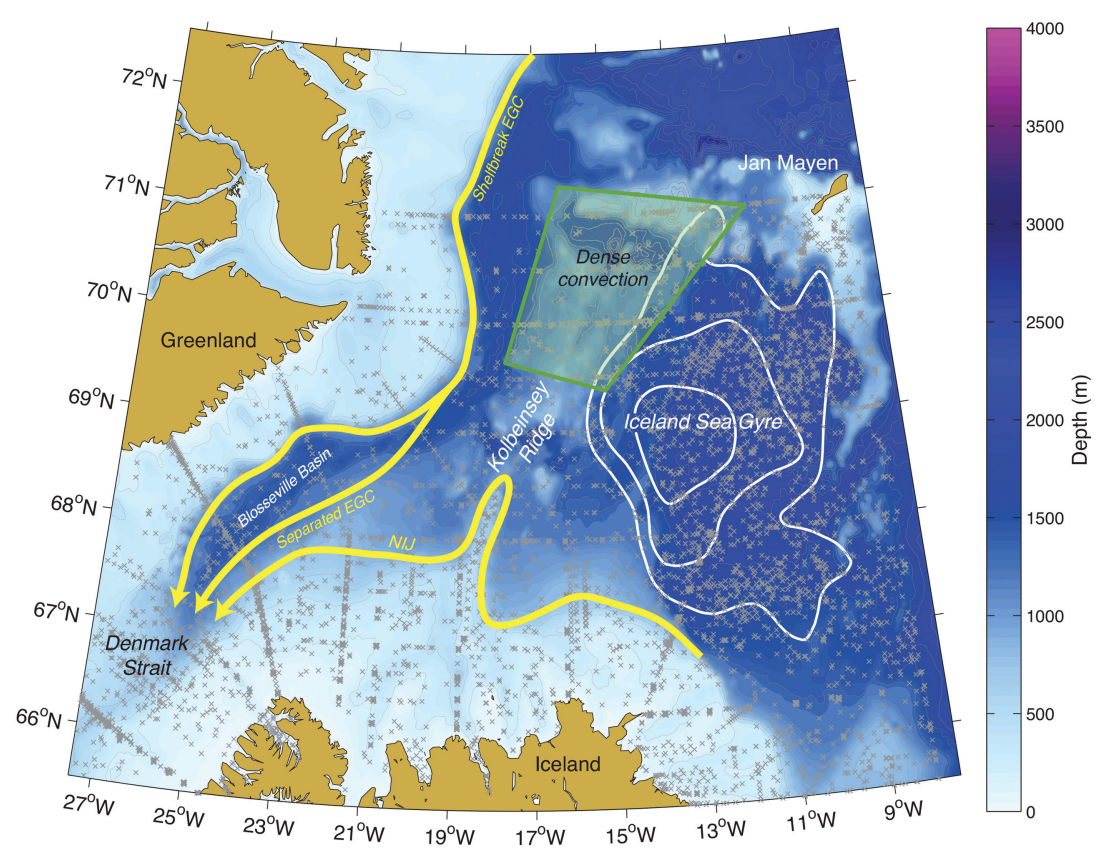

Figure 16. Region of the deepest and densest winter mixed layers in the Iceland Sea (green shading) based on a combination of shipboard data, Argo float data, and glider data (Våge et al. 2015; K. Våge, personal communication, 2016). The dynamic height contours of the Iceland Sea gyre are indicated by the white lines (from Våge et al. 2013). The pathways of the shelf break East Greenland Current (EGC), separated EGC, and North Icelandic Jet (NIJ) are shown schematically by the yellow lines. The locations of the data used by Vage et al. (2015) are indicated by the gray crosses.

between the Kolbeinsey Ridge and the continental slope east of Greenland: annual mean precipitation, freshwater flux from the coastal region, and ice flux from the coastal region. Consider first the precipitation. The annual mean net evaporation minus precipitation is approximately $E=-1.2 \times 10^{-8} \mathrm{~m} \mathrm{~s}^{-1}$, based on the ERAI and JRA55 climatologies. The area of deep convection in Figure 16 is approximately $A=3 \times 10^{10} \mathrm{~m}^{2}$. If the $0.5 \mathrm{~Sv}$ of NIIC water were to flow into this region, gain freshwater through wintertime convection of the net evaporation minus precipitation over the depth of the outflowing NIJ ( $\sim 500 \mathrm{~m})$, this would result in a change in mean salinity of only 0.02 , an order of magnitude less than the observed change. The freshwater transport is given by $E S_{o} A$ (where $S_{o}$ is the salinity of the outflow), which is approximately $12 \mathrm{mSv}$, again an order of magnitude too small.

Now consider the other two sources of freshwater. Based on an extensive hydrographic survey along the shelf/slope of east Greenland from Fram Strait to Denmark Strait (Håvik et al. 2017), the liquid freshwater transport of the EGC decreases by approximately $50 \mathrm{mSv}$ 
between $72^{\circ} \mathrm{N}$ and $69^{\circ} \mathrm{N}$ (Fig. 16). ${ }^{2}$ The freshwater transport of the East Icelandic Current (which is believed to emanate from the EGC near $70^{\circ} \mathrm{N}$ ) is only $3.4 \mathrm{mSv}$ (Macrander, Valdimarsson, and Jónsson 2014); hence, most of the $\sim 50 \mathrm{mSv}$ fluxed from the boundary should enter the region where the convection occurs. This is half of what is required to achieve the observed outflow salinity. Regarding the solid freshwater flux, Dodd et al. (2009) used hydrographic measurements, oxygen isotope ratio data, and dissolved barium data from sections just north of Denmark Strait to estimate that ice loss from the east Greenland shelf south of Fram Strait accounts for roughly another $50 \mathrm{mSv}$ of freshwater flux into the interior. Thus, it appears that the mean change in salinity for the densest half of the NIIC-NIJ overturning loop can be explained by freshwater sources on the east Greenland shelf/slope with an implied mixing and exchange in the northwest Iceland Sea. We hasten to note that these fluxes are based on only a small amount of data, and we cannot say for certain if significant mixing takes place in this region. However, we offer this as a plausible scenario. The other $0.5 \mathrm{~Sv}$ of NIJ transport presumably emanates from east of the Kolbeinsey Ridge and must attain an additional $100 \mathrm{mSv}$ from other freshwater sources. At this point, it is difficult to speculate what these sources are because very little is known about the remaining contributions to the NIJ.

The next question is, why are fluctuations of salinity in the NIIC in phase with-but larger than - those of the NIJ (Fig. 15)? The low frequency variability in salinity of the Atlantic water entering Denmark Strait has been described by Hátún et al. (2005) and Häkkinen, Rhines, and Worthen (2011) and is similar to that observed in the other two primary branches of the Atlantic inflow to the Nordic Seas farther to the east. These previous studies have shown that this variability is a result of large-scale changes to the subpolar and subtropical gyre circulation patterns, driven by changes in the wind stress curl over the subpolar gyre. During periods of weakening cyclonic wind stress curl, the subpolar front shifts to the west, and the warm, saline subtropical gyre waters penetrate farther to the north in the eastern Atlantic, directly affecting the salinity of the waters flowing into the Nordic Seas. Between the late 1990s and at least 2010, the wind forcing over the subpolar gyre was decreasing, and saline subtropical waters were advected northward into the northeast Atlantic and Nordic Seas, consistent with the NIIC trend seen in Figure 15.

It is tempting to interpret the in-phase changes in the salinity of the outflowing NIJ as a direct consequence of the variability in the inflowing Atlantic water. Such a relationship would imply a short residence time of the Atlantic water in the Nordic Seas that enters via the NIIC. However, as noted previously, the magnitude of the salinity changes observed in the NIJ is an order of magnitude less than the salinity changes in the NIIC. This in turn would imply a very long residence time and strong mixing in order to dampen the salinity signal. The in-phase relationship, coupled with the disparity in signal strength, suggests that changes in the outflow salinity are not simply reflecting changes in the inflow salinity with a short residence time in the Nordic Seas.

2. The freshwater transports in Håvik et al. (2017) are relative to 34.8, but the values change very little when calculated relative to 34.9 (L. Håvik, personal communication, 2016). 

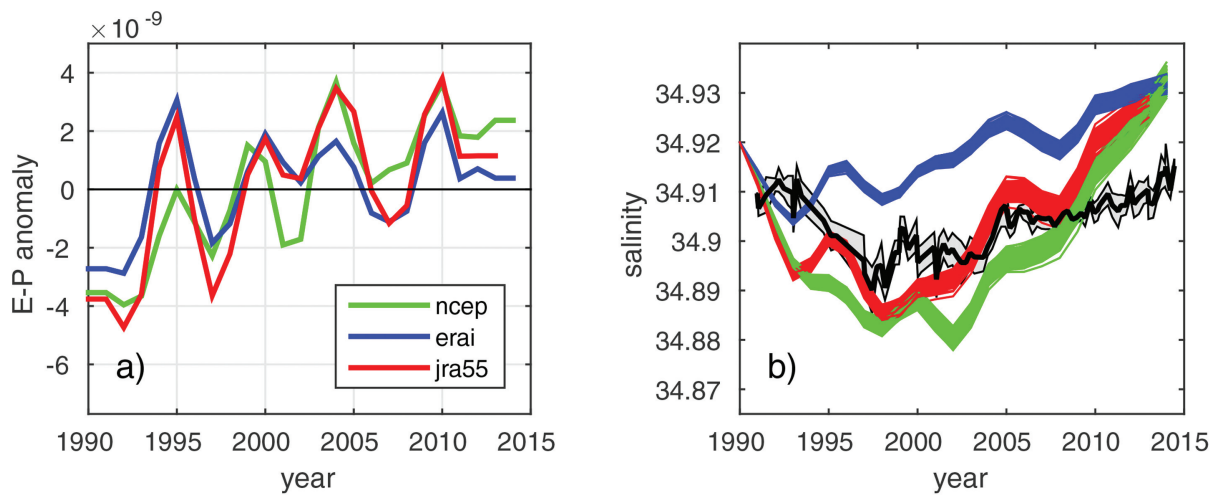

Figure 17. (a) Annual anomalies of evaporation minus precipitation (E-P; $\mathrm{m} \mathrm{s}^{-1}$ ) from the three different reanalysis products (see the legend). The anomalies are relative to the 25 -year mean. (b) The resulting variation in salinity of the North Icelandic Jet (NIJ) water mass using the E-P forcing in panel (a) with the one-dimensional mixing salinity evolution equation (including error estimates; see text). The thick black line is the observed NIJ salinity from Figure 15 with \pm 1 standard deviation indicated by the gray shading. ERAI, ERA-Interim product; JRA55, Japanese Meteorological Agency product; NCEP, National Centers for Environmental Prediction product.

Another potential source of variability in the outflow salinity is variability in the sources of freshwater in the Nordic Seas. There could be low-frequency trends in the freshwater and/or ice flux from the east Greenland shelf/slope, which might imprint such a signal on the product water formed by convection. We cannot discount this but also have no means to estimate these fluxes over the 25-year time period of our analysis. We can, however, estimate the changes in the salinity of the convective water mass that results from local changes in evaporation minus precipitation (E-P). Time series of E-P anomalies over the Iceland Sea $\left(69^{\circ} \mathrm{N}\right.$ to $71^{\circ} \mathrm{N}, 17.4^{\circ} \mathrm{W}$ to $13^{\circ} \mathrm{W}$ ) from 1990 to 2014 are shown in Figure 17 (a) for three reanalysis products: NCEP, ERAI, and JRA55 (see Section 2b for a description of these products). They each show similar patterns with interannual oscillations of $\mathrm{O}(5$ year) period and a nearly linear trend of increasing E-P anomaly. The uncertainty between the three estimates of E-P is on the order of $10 \%$, a result that is in agreement with the reported uncertainties in the underlying fluxes (Bosilovich et al. 2008; Renfrew et al. 2009). Over roughly the first 10 years there is an excess of precipitation, and over the final 15 years there is a deficit of precipitation.

The influence of this local net surface forcing on a water column of thickness $H=500$ m can be estimated by integrating the salinity evolution equation $\partial S / \partial t=S_{r} E^{\prime} / H$, where $S_{r}=35$ is a reference salinity and $E^{\prime}$ is the anomalous E-P flux (relative to the mean from 1990 to 2014). This equation assumes that a net freshwater flux of E-P (with $S=0$ ) mixes with a water column of thickness $H$ and salinity $S_{r}$. This approach is valid as long as E-P $<<H / t$, where $t$ is the time of integration (which is the case here). The resulting time series of salinity, assuming an initial value of 34.92, is shown in Figure 17(b). We performed 
100 calculations for each of the forcing products, with a random $10 \%$ of the root-meansquare variability in E-P added at each year to represent the expected range of uncertainty. The phase and amplitude of the predicted salinity are in broad agreement with the salinity observed in the NIJ (the one-dimensional NCEP and JRA55 models tend to overpredict the variability). This interpretation of local atmospheric forcing is supported by a time series of the near-surface salinity in the center of the Iceland Sea gyre, which displays a similar in-phase relationship with both the NIIC and the NIJ (not shown). The center of the gyre is within a region of closed dynamic height contours; hence, it is expected that exchange between the gyre and the surrounding ocean occurs on long timescales. This points to the importance of air-sea forcing versus lateral exchange in dictating the variability in salinity in this region.

The uncertainties of the E-P fields and the gross simplification of the one-dimensional model notwithstanding, we conclude from this that E-P over the region of dense water formation is potentially responsible for the observed variability in the salinity of the NIJ. The in-phase relationship between the forcing over the convection region and the observed outflow in the NIJ implies a fairly rapid communication between the convection site and the outflow. A modest advective speed of $\mathrm{O}\left(1 \mathrm{~cm} \mathrm{~s}^{-1}\right)$ would transmit water from the convection site to the Kögur line in roughly 1 year, consistent with the phase relationship in Figure 17(b).

Given the notion that the NIJ salinity variations are largely attributable to local atmospheric forcing and not the result of the inflowing NIIC, why then are the two time series in Figure 15 in phase? As noted previously, the variability in the salinity of the NIIC appears to be forced by variations in the wind stress curl in the subpolar gyre. Using the three reanalysis products, we calculated the annual wind stress curl over approximately $46-58^{\circ} \mathrm{N}, 24-2^{\circ} \mathrm{W}$ going back to 1958 (the ERAI product only starts in 1979). The negative of the annual E-P anomaly calculated over the convection region in the Iceland Sea from JRA55 is plotted together with the spatially averaged wind stress curl anomaly from the three products in Figure 18. Each of the time series has been detrended and smoothed using a [0.25 0.5 0.25] filter. One sees that there is a clear relationship. Over the period of overlap between the three reanalyses (1979-2013), the correlation coefficients between the E-P and curl are -0.48 , -0.43 , and -0.51 for the NCEP, JRA55, and ERAI products, respectively. Using a Monte Carlo approach that uses 100,000 synthetic time series with the same red noise spectral characteristics as the underlying time series (Rudnick and Davis 2003; Moore et al. 2015), these correlations are all statistically significant at the $95 \%$ confidence level (although the amount of variance explained is only on the order of $25 \%$ ).

This result indicates that the large-scale weather patterns that control the low-frequency variability of the wind stress curl over the subpolar North Atlantic also influence the E-P fields over the Iceland Sea. Further investigation is needed to identify the precise mechanisms at work, although this is likely related to the nature of the regional storm tracks (Chang 2009) and teleconnection patterns that influence the location of the Icelandic Low (Moore et al. 2013). Finally, we stress that, despite the in-phase relationship in salinity between 


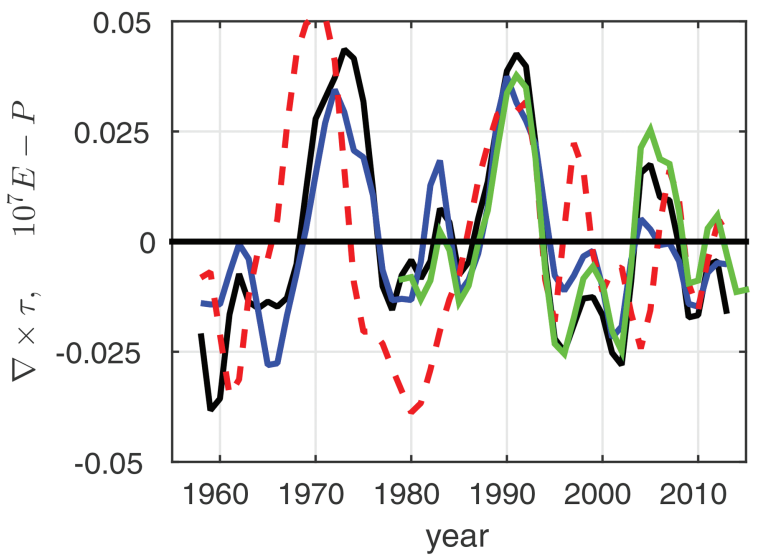

Figure 18. The evaporation minus precipitation (E-P) anomaly $\left(\mathrm{m} \mathrm{s}^{-1}\right)$ from JRA55, smoothed using

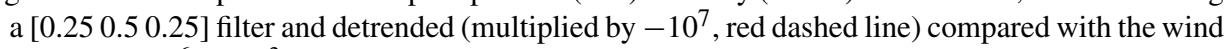
stress curl $\left(10^{6} \mathrm{~N} \mathrm{~m}^{-3}\right)$ from the three reanalysis products averaged over the region $46^{\circ}-58^{\circ} \mathrm{N}, 24^{\circ}-$ $2^{\circ} \mathrm{W}$, also smoothed and detrended: NCEP (black line), ERAI (green line), and JRA55 (blue line). ERAI, ERA-Interim product; JRA55, Japanese Meteorological Agency product; NCEP, National Centers for Environmental Prediction product.

the inflowing NIIC and outflowing NIJ (Fig. 15), this does not imply that the Iceland Sea overturning loop operates on an annual timescale. It is still unknown how long it takes the Atlantic water flowing through Denmark Strait to be transformed into overflow water and exported out of the Iceland Sea to the North Atlantic. We note, however, that based on the volume of the transformation region in the northwest Iceland Sea (for the $A$ and $H$ given previously), an overturning circulation of $0.5 \mathrm{~Sv}$ implies a residence time of approximately 1 year. This, together with the swift E-P imprint onto the NIJ (Fig. 17b), implies that the Iceland Sea overturning cell is rapid.

\section{Summary}

In this study, we have elucidated the relationship between the NIJ, which transports the densest overflow water into Denmark Strait, and the NIIC, which imports Atlantic water into the Iceland Sea. Using a set of eight shipboard hydrographic/velocity sections at the Kögur line, roughly $200 \mathrm{~km}$ northeast of Denmark Strait, we quantified the water mass and kinematic structure of both currents. The NIIC is a surface-intensified current residing on the outer shelf, which in summer is more baroclinic. Seaward of the shelf break, the middepth-intensified NIJ transports Arctic-origin overflow water equatorward. All three winter occupations displayed a double-cored NIJ, whereas the summer mean showed a single, stronger NIJ inshore of the surface-intensified separated EGC. The mean transport of the NIJ was $1.23 \pm 0.32 \mathrm{~Sv}$, while that of the NIIC was $3.07 \pm 0.29 \mathrm{~Sv}$. However, when excluding the anomalously large NIIC value in February 2011, and distinguishing the warm, 
salty inflow from the cold, fresh outflow, the two resulting transports more closely balance each other (within the error bars).

Using additional shipboard transects around the north slope of Iceland, we demonstrated that in some instances the NIJ and NIIC were situated immediately adjacent to each other, in which case a single density front supported both currents. In the remaining instances, the NIIC was located well inshore of the NIJ. However, in each of those instances a separate, surface-intensified poleward flow resided next to the NIJ. A clear trend emerged: when the NIIC and NIJ were situated side by side, the density front was strong, the poleward flow was substantial, and the water advected by the poleward flow was salty. By contrast, when the two currents were apart, the density front associated with the NIJ was weak, the poleward flow next to the NIJ was reduced, and the water within the poleward flow was fresher. In all cases, the density front is dictated by the lateral gradient in temperature (colder onshore, warmer offshore). It is unclear why the NIJ is always associated with such a density front and poleward flow, although it appears that the NIJ and NIIC "lock" to each other when the bottom topography steers them close together.

Performing an analysis in density space on the eight Kögur sections, we demonstrated that the dense water advected by the NIJ has become markedly warmer and saltier over the past several years. Extending this back in time using historical hydrographic data revealed that there has been significant interannual variability of this water mass over the past 25 years. Comparing this variability with that of the boluses of overflow water passing through Denmark Strait indicates that the dense water becomes warmer between the Kögur line and the sill, with more year-to-year scatter. This is likely because of intermittent mixing along the NIJ pathway.

Strikingly, the interannual variability in salinity of the inflowing NIIC matches that of the outflowing NIJ with little to no phase lag. This would seem to imply that the latter is being dictated by the former, and that the overturning loop in the Iceland Sea is rapid (i.e., on the order of a year). This precludes the central Iceland Sea gyre as a likely source of the transformation. However, recent data indicate that the deepest and densest winter mixed layers occur outside the gyre in the northwest Iceland Sea. We demonstrated that the combination of liquid and solid freshwater flux from the east Greenland boundary to the northwest Iceland Sea can account for the observed net freshening of the NIIC to the NIJ for the densest $0.5 \mathrm{~Sv}$ of the overturning circulation. This implies that the remaining $0.5 \mathrm{~Sv}$ of overturning occurs farther to the east, which is in line with previous model studies.

Because of the large disparity in signals, the interannual variability in salinity of the NIJ cannot simply be dictated by the corresponding variability of the NIIC. We showed that the year-to-year changes in the salinity of the dense outflow are instead explainable by annual anomalies of E-P in the Iceland Sea. We cannot preclude other possibilities, such as having only a small fraction of the anomalously saline NIIC contribute to the NIJ, but this would contradict previous studies that suggest that much of the NIJ originates from the NIIC. Accordingly, the in-phase relationship between the NIIC and NIJ appears to be dictated by large-scale atmospheric patterns. Previous studies have revealed that variations in the 
wind stress curl over the subpolar gyre dictate the salinity of the Atlantic water entering the Nordic Seas. Using reanalysis fields, we demonstrated that the weather patterns controlling the curl also influence the E-P fields over the Iceland Sea. Although our study has shed light on the nature and variability of the overturning loop in the Iceland Sea, further work is required to better understand the mechanisms and timescales involved.

Acknowledgments. Three different research vessels were involved in the collection of the data used in the study: the R/V Bjarni Samundsson, the R/V Knorr, and the RRS James Clark Ross. We are indebted to the crews of each of these vessels for their hard work, expertise, and dedication in making the scientific operations successful. Many watch standers and students sailed on the cruises and helped collect the measurements. Funding for the project was provided by the National Science Foundation under grants OCE-1558742 (RSP, MAS, DJT, CN), OCE-1433170 (MAS), and OCE-0959381 (DM); the Norwegian Research Council under grant agreement no. 231647 (KV); the Bergen Research Foundation (KV); the European Union Seventh Framework Programme (FP7 2007-2013) under grant agreement 308299 (NACLIM project, KV, HV, and SJ); and the Natural Sciences and Engineering Research Council of Canada (GWKM).

\section{REFERENCES}

Aksenov, Y., S. Bacon, A. C. Coward, and A. J. G. Nurser. 2010. The North Atlantic inflow to the Arctic Ocean: High-resolution model study. J. Mar. Syst., 79, 1-22. doi: 10.1016/j.jmarsys.2009.05.003

Behrens, E., K. Våge, B. Harden, A. Biastoch, and C. W. Böning. 2017. Composition and variability of the Denmark Strait Overflow Water in a high-resolution numerical model hindcast simulation. J. Geophys. Res.: Oceans, 122, 2830-2846. doi: 10.1002/2016JC012158

Bosilovich, M. G., J. Chen, F. R. Robertson, and R. F. Adler. 2008. Evaluation of global precipitation in reanalyses. J. Appl. Meteorol. Climatol., 47, 2279-2299. doi: 10.1175/2008JAMC1921.1

Chang, E. K. M. 2009. Are band-pass variance statistics useful measures of storm track activity? Reexamining storm track variability associated with the NAO using multiple storm track measures. Clim. Dyn., 33, 277-296. doi: 10.1007/s00382-009-0532-9

Cooper, L. H. N. 1955. Deep water movements in the North Atlantic as a link between climatic changes around Iceland and biological productivity of the English Channel and Celtic Sea. J. Mar. Res., 14, 347-362.

Dee, D. P., S. M. Uppala, A. J. Simmons, P. Berrisford, P. Poli, S. Kobayashi, U. Andrae, et al. 2011. The ERA-Interim reanalysis: Configuration and performance of the data assimilation system. Q. J. R. Meteorol. Soc., 137(656), 553-597. doi: 10.1002/qj.828

de Steur, L., E. Hansen, C. Mauritzen, A. Beszczynska-Möller, and E. Fahrbach. 2014. Impact of recirculation on the East Greenland Current in Fram Strait: Results from moored current meter measurements between 1997 and 2009. Deep Sea Res., Part I, 92, 26-40. doi: 10.1016/j.dsr.2014.05.018

Dickson, R. R., and J. Brown. 1994. The production of North Atlantic Deep Water: Sources, rates, and pathways. J. Geophys. Res.: Oceans, 99(C6), 12319-12341. doi: 10.1029/94JC00530

Dickson, R. R., S. Dye, S. Jonsson, A. Kohl, A. Macrander, M. Marnela, J. Meincke, S. Olsen, B. Rudels, H. Valdimarsson, and G. Voet, 2008. The overflow flux west of Iceland: Variability, origins and forcing, in Arctic-Subarctic Ocean Fluxes: Defining the role of the northern seas in climate, editor R. R. Dickson, J. Meincke, and P. Rhines. Springer. 443-474.

Dodd, P. A., K. J. Heywood, M. P. Meredith, A. C. Naveira-Garabato, A. D. Marca, and K. K. Falkner. 2009. Sources and fate of freshwater exported in the East Greenland Current. Geophys. Res. Lett., 36, L19608. doi: 10.1029/2009GL039663 
Dukhovskoy, D. S., P. G. Myers, G. Platov, M.-L. Timmermans, B. Curry, A. Proshutinsky, J. L. Bamber, et al. 2016. Greenland freshwater pathways in the sub-Arctic seas from model experiments with passive tracers. J. Geophys. Res.: Oceans, 121, 877-907. doi: 10.1002/2015JC011290

Egbert, G. D., and S. Y. Erofeeva. 2002. Efficient inverse modeling of barotropic ocean tides. J. Atmos. Oceanic Technol., 19(2), 183-204. doi: 10.1175/1520-0426(2002)019<0183: EIMOBO $>2.0 . \mathrm{CO} ; 2$

Firing, E., and R. Gordon. 1990. Deep ocean acoustic Doppler current profiling, in Proceedings of the IEEE Fourth Working Conference on Current Measurement, Clinton, MD. New York: Institute of Electrical and Electronics Engineers (IEEE), 192-201.

Fischer, J., and M. Visbeck. 1993. Deep velocity profiling with self-contained ADCPs. J. Atmos. Oceanic Technol., 10, 764-773. doi: org/10.1175/1520-0426(1993)010\%3C0764:DVPWSC\% 3E2.0.CO;2

Gierz, P., G. Lohmann, and W. Wei. 2015. Response of Atlantic overturning to future warming in a coupled atmosphere-ocean-ice sheet model. Geophys. Res. Lett., 42, 6811-6818. doi: 10.1002/2015GL065276

Häkkinen, S., P. B. Rhines, and D. L. Worthen. 2011. Warm and saline events embedded in the meridional circulation of the northern North Atlantic. J. Geophys. Res.: Oceans, 116, C03006. doi: 10.1029/2010JC006275

Hansen, B., H. Hatun, R. Kristiansen, S. M. Olsen, and S. Østerhus. 2010. Stability and forcing of the Iceland-Faroe inflow of water, heat, and salt to the Arctic. Ocean Sci., 6, 1013-1026. doi: 10.5194/os-6-1013-2010

Hansen, B., and S. Østerhus. 2000. North Atlantic-Nordic Seas exchanges. Prog. Oceanogr., 45, 109-208. doi: 10.1016/S0079-6611(99)00052-X

Harden, B. E., R. S. Pickart, H. Valdimarsson, K. Våge, L. de Steur, C. Richards, F. Bahr, et al. 2016. Upstream sources of the Denmark Strait overflow: Observations from a high-resolution mooring array. Deep Sea Res., Part I, 112, 94-112. doi: 10.1016/j.dsr.2016.02.007

Hattermann, T., P. E. Isachsen, W.-J. von Appen, J. Albretsen, and A. Sundfjord. 2016. Eddydriven recirculation of Atlantic Water in Fram Strait. Geophys. Res. Lett., 43(7), 3406-3414. doi: 10.1002/2016GL068323

Hátún, H., A. B. Sand $\varnothing$, H. Drange, B. Hansen, and H. Valdimarsson. 2005. Influence of the Atlantic Subpolar Gyre on the thermohaline circulation. Science, 309, 1841-1844. doi: 10.1126/ science. 1114777

Håvik, L., R. S. Pickart, K. Våge, D. Torres, A. M. Thurnherr, A. Beszczynska-Möller, W. Walczowski, and W.-J. von Appen. 2017. Evolution of the East Greenland Current from Fram Strait to Denmark Strait: Synoptic measurements from summer 2012. J. Geophys. Res.: Oceans, 122, 1974-1994. doi: 10.1002/2016JC012228

Isachsen, P. E. 2011. Baroclinic instability and eddy tracer transport across sloping bottom topography: How well does a modified Eady model do in primitive equation simulations? Ocean Modell., 39, 183-199. doi: 10.1016/j.ocemod.2010.09.007

Isachsen, P. E. 2015. Baroclinic instability and the mesoscale eddy field around the Lofoten Basin. J. Geophys. Res.: Oceans, 120, 2884-2903. doi: 10.1002/2014JC010448

Jochumsen, K., D. Quadfasel, H. Valdimarsson, and S. Jónsson. 2012. Variability of the Denmark Strait overflow: Moored time series from 1996-2011. J. Geophys. Res.: Oceans, 117, C12003. doi: 10.1029/2012JC008244

Jochumsen, K., M. Köllner, D. Quadfasel, S. Dye, B. Rudels, and H. Valdimarsson (2015). On the origin and propagation of Denmark Strait overflow water anomalies in the Irminger Basin. J. Geophys. Res. Oceans, 120, 1841-1855, doi: 10.1002/2014JC010397 
Jochumsen, K., M. Moritz, N. Nunes, D. Quadfasel, K. M. H. Larsen, B. Hansen, H. Valdimarsson, and S. Jonsson (2017). Revised transport estimates of the Denmark Strait overflow. J. Geophys. Res. Oceans, 122, 3434-3450. doi: 10.1002/2017JC012803

Jonsson, S., and H. Valdimarsson. 2004. A new path for the Denmark Strait overflow water from the Iceland Sea to Denmark Strait. Geophys. Res. Lett., 31, L03305. doi: 10.1029/2003GL019214

Jónsson, S., and H. Valdimarsson. 2005. The flow of Atlantic water to the North Icelandic Shelf and its relation to the drift of cod larvae. ICES J. Mar. Sci., 62, 1350-1359. doi: 10.1016/j.icesjms.2005.05.003

Jónsson, S., and H. Valdimarsson. 2012. Water mass transport variability to the north Icelandic shelf, 1994-2010. ICES J. Mar. Sci., 69, 809-815. doi: 10.1093/icesjms/fss024

Kalnay, E., M. Kanamitsu, R. Kistler, W. Collins, D. Deaven, L. Gandin, M. Iredell, et al. 1996. The NCEP/NCAR 40-year reanalysis project. Bull. Am. Meteorol. Soc., 77, 437-471. doi: 10.1175/1520-0477(1996)077\%3C0437:TNYRP\%3E2.0.CO;2

Kobayashi, S., Y. Ota, Y. Harada, A. Ebita, M. Moriya, H. Onoda, K. Onogi, et al. 2015. The JRA-55 reanalysis: General specifications and basic characteristics. J. Meteorol. Soc. Jpn., 93, 5-48. doi: 10.2151/jmsj.2015-001

Köhl, A., R. H. Käse, D. Stammer, and N. Serra. 2007. Causes of changes in the Denmark Strait overflow. J. Phys. Oceanogr., 37(6), 1678-1696. doi: 10.1175/JPO3080.1

Macrander, A., U. Send, H. Valdimarsson, S. Jónsson, and R. H. Käse. 2005. Interannual changes in the overflow from the Nordic Seas into the Atlantic Ocean through Denmark Strait. Geophys. Res. Lett., 32(6), L06606. doi: 10.1029/2004GL021463

Macrander, A., H. Valdimarsson, and S. Jónsson. 2014. Improved transport estimate of the East Icelandic Current 2002-2012. J. Geophys. Res.: Oceans, 119(6), 3407-3424. doi: 10.1002/ 2013JC009517

Mastropole, D., R. S. Pickart, H. Valdimarsson, K. Våge, K. Jochumsen, and J. B. Girton. 2017. Hydrographic structure of overflow water passing through Denmark Strait. Journal of Geophysical Research, 122, 306-321, doi: 10.1002/2016JC012007.

Mauritzen, C. 1996. Production of dense overflow waters feeding the North Atlantic across the Greenland-Scotland Ridge. Part 1: Evidence for a revised circulation scheme. Deep Sea Res., Part I, 43, 769-806. doi: 10.1016/0967-0637(96)00037-4

Moore, G. W. K., I. A. Renfrew, and R. S. Pickart. 2012. Spatial distribution of air-sea heat fluxes over the sub-polar North Atlantic Ocean. Geophys. Res. Lett., 39, L18806. doi: 10.1029/2012GL053097

Moore, G. W. K., I. A. Renfrew, and R. S. Pickart, 2013. Multi-decadal mobility of the North Atlantic Oscillation. Journal of Climate, 26, 2453-2466, doi: 10.1175/JCLI-D-12-00023.1

Moore, G. W. K., K. Våge, R. S. Pickart, and I. A. Renfrew. 2015. Decreasing intensity of open-ocean convection in the Greenland and Iceland seas. Nat. Clim. Change, 5, 877-882. doi: $10.1038 / \mathrm{ncli}$ mate2688

Nilsen, J. E. Ø., H. Hátún, K. A. Mork, and H. Valdimarsson. 2008. The NISE Dataset. Technical Report 08-01. Tórshavn, Faroe Islands: Faroese Fisheries Laboratory.

Quadfasel, D., J.-C. Gascard, and K.-P. Koltermann. 1987. Large-scale oceanography in Fram Strait during the 1984 Marginal Ice Zone Experiment. J. Geophys. Res.: Oceans, 92(C7), 6719-6728. doi: 10.1029/JC092iC07p06719

Renfrew, I. A., G. W. K. Moore, P. S. Guest, and K. Bumke. 2002. A comparison of surface layer and surface turbulent flux observations over the Labrador Sea with ECMWF analyses and NCEP reanalyses. J. Phys. Oceanogr., 32, 383-400. doi: 10.1175/1520-0485(2002)032\%3C0383: ACOSLA\%3E2.0.CO;2

Renfrew, I. A., G. N. Petersen, D. A. J. Sproson, G. W. K. Moore, H. Adiwidjaja, S. Zhang, and R. North. 2009. A comparison of aircraft-based surface-layer observations over Denmark Strait and 
the Irminger Sea with meteorological analyses and QuikSCAT winds. Q. J. R. Meteorol. Soc., 135, 2046-2066. doi: 10.1002/qj.444

Rudels, B., E. Fahrbach, J. Meincke, G. Budeus, and P. Eriksson, 2002. The East Greenland Current and its contribution to the Denmark Strait overflow. ICES Journal of Marine Science, 219, 319-325.

Rudnick, D. L., and R. E. Davis. 2003. Red noise and regime shifts. Deep Sea Res., Part I, 50, 691-699. doi: 10.1016/S0967-0637(03)00053-0

Spall, M. A. 2010. Non-local topographic influences on deep convection: An idealized model for the Nordic Seas. Ocean Modell., 32, 72-85. doi: 10.1016/j.ocemod.2009.10.009

Thurnherr, A. M. 2010. A practical assessment of the errors associated with full-depth LADCP profiles obtained using Teledyne RDI Workhorse acoustic Doppler current profilers. J. Atmos. Oceanic Technol., 27, 1215-1227. doi: 10.1175/2010JTECHO708.1

Thurnherr, A. M., 2014. How to Process LADCP Data with the LDEO Software. New York: Columbia University. ftp://ftp.ldeo.columbia.edu/pub/LADCP/HOWTO/LDEO_IX.pdf

Våge, K., G. W. K. Moore, S. Jónsson, and H. Valdimarsson. 2015. Water mass transformation in the Iceland Sea. Deep Sea Res., Part I, 101, 98-109. doi: 10.1016/j.dsr.2015.04.001

Våge, K., R. S. Pickart, M. A. Spall, G. W. K. Moore, H. Valdimarsson, D. J. Torres, S. Y. Erofeeva, and J. E. Ø. Nilsen. 2013. Revised circulation scheme north of the Denmark Strait. Deep Sea Res., Part I, 79, 20-39.

Våge, K., R. S. Pickart, M. A. Spall, H. Valdimarsson, S. Jónsson, D. J. Torres, S. Østerhus, and T. Eldevik. 2011. Significant role of the North Icelandic Jet in the formation of Denmark Strait overflow water. Nat. Geosci., 4, 723-727. doi: 10.1038/ngeo1234

Valdimarsson, H., and S.-A. Malmberg. 1999. Near-surface circulation in Icelandic waters derived from satellite tracked drifters. Rit Fiskideildar, 16, 23-39.

Visbeck, M. 2002. Deep velocity profiling using lowered acoustic Doppler current profilers: Bottom track and inverse solutions. J. Atmos. Oceanic Technol., 19, 794-807. doi: 10.1175/15200426(2002)019\%3C0794:DVPULA\%3E2.0.CO;2

Yang, J., and L. J. Pratt. 2014. Some dynamical constraints on upstream pathways of the Denmark Strait overflow. J. Phys. Oceanogr., 44, 3033-3053. doi: 10.1175/JPO-D-13-0227.1

Received: 23 January 2017; revised: 2 August 2017. 